\title{
Antecedentes de los epígrafes de la poesía de Quevedo en la literatura clásica y del Siglo de Oro. Con una hipótesis sobre su autoría
}

\author{
María José Alonso Veloso \\ Universidad de Santiago de Compostela
}

\section{RESUMEN}

Muchos de los autores griegos y latinos redactaron epígrafes a sus poemas, como también lo hicieron escritores italianos y españoles del Siglo de Oro imitados por Francisco de Quevedo. Sus autógrafos y numerosas composiciones tempranas, recogidas en antologías de principios del siglo XVII, contienen también estos títulos, que figuran tanto en la edición póstuma de la poesía quevediana de 1648, debida a González de Salas, como en la de 1670, supervisada por Pedro Aldrete. El presente artículo tiene el propósito de revisar el problema de la autoría de tales epígrafes, atribuidos mayoritariamente por la crítica a su primer editor.

Palabras clave: tradición clásica y renacentista de los epígrafes, poesía de Quevedo, autógrafos, poemas tempranos, las ediciones de 1648 y 1670, autoría de los epígrafes, el papel de González de Salas.

\section{Classical, renaissance and baroque antecedents of Quevedo's titles of his poetry. With a hypothesis on their authorship}

\begin{abstract}
Many Greek and Latin authors imitated by Francisco de Quevedo wrote their poems with title, as well as italian and spanish writers of XVI ${ }^{\text {th }}$ and XVII ${ }^{\text {th }}$ centuries did. Quevedo's autographs and many of his earliest hand-written or published poems have titles too and they also appear in Quevedo's posthumous editions, published in 1648, by González de Salas, and 1670, by Pedro Aldrete. This article tries to revise the matter of the authorship of this titles, that most critics have attributed to the first editor.
\end{abstract}

Key Words: classical and Renaissance titles, Quevedo's poetry, Autographs, The earliest poems. The editions of 1648 and 1670, Title's authorship, González de Salas' role.

La costumbre de anteponer un título a ciertos poemas líricos breves, de carácter amoroso, moral o satírico, se gestó ya en la antigüedad grecolatina. Este paratexto, inicialmente manuscrito, se convirtió en práctica editorial fre- 
cuente con la imprenta, no sólo en ediciones y traducciones de autores clásicos, que proliferaron en el Siglo de Oro, sino también en las de muchos escritores españoles en lengua romance de los siglos XVI y XVII. Los epígrafes - término que considero equivalente a la actual acepción de «título»— eran por lo general una síntesis del tema del poema e iban seguidos en ocasiones por subepígrafes, explicaciones complementarias que podían contextualizar el texto literario o aclarar circunstancias con él relacionadas. Como tantas ediciones de la época, la de la poesía de Quevedo, publicada póstumamente por González de Salas, en 1648, contiene epígrafes —y a veces subepígrafes- de forma mayoritaria ${ }^{1}$; lo mismo sucede con la segunda parte, a cargo de Aldrete, en 1670, que también incorpora títulos en casi todos los poemas. Aunque

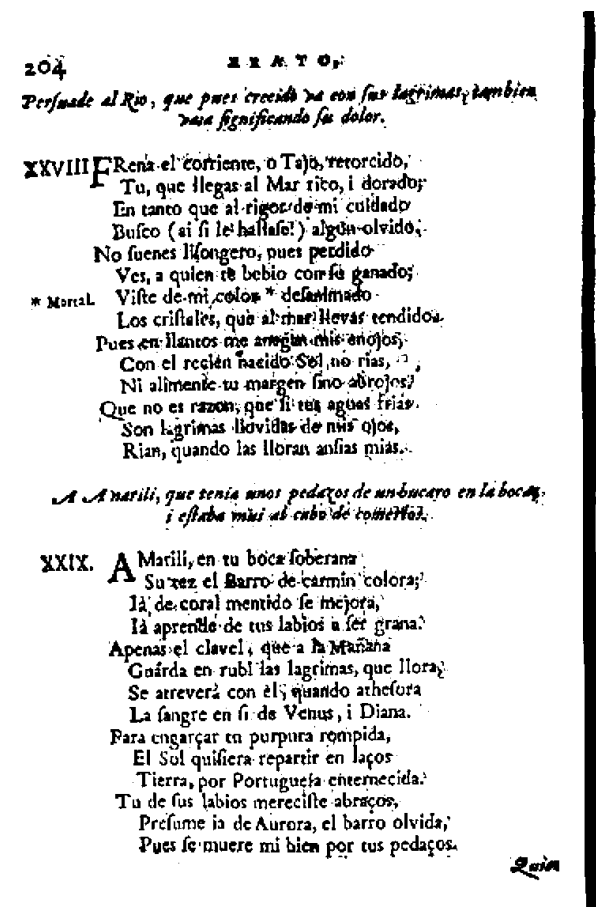

$\tan x$

\section{Quiere, que la berinofura conffta end morsimiento.}

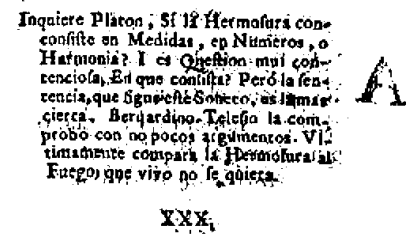

No exancifec, no da symmetra

- De a hemofura, que, of Flovalla, veo

- Ni cerat de los Numctós trophieó

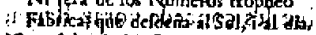

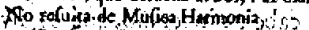

(Perdunen Yus nilagros en onphoc)

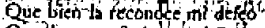

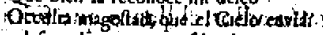

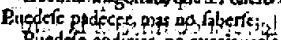

Puedéc codíciar, no averiguarite

Alma, que en movimienros piedeverfe.

No puede en la quietud difunta hallarie

Hemofura, que es Fnego encl moverie,

I. no puede viviénido*t lofegarfe,

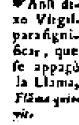

W25

20

LÁminA 1. Imagen de la primera edición de Parnaso (1648).

${ }^{1}$ En la lámina 1, correspondiente al soneto XXX del apartado dedicado a la primera sección de la musa IV, Erato, se aprecian con claridad los distintos paratextos utilizados en la edición póstuma de la poesía de Quevedo: denomino epígrafe o título al texto "Quiere, que la hermosura consista en el movimiento»; subepígrafe, a la aclaración subsiguiente, «Inquiere Platón [...] que vivo no se quieta». En este caso, el poema cuenta también con una nota filológica en el margen derecho de la página, que desvela la fuente clásica: «Ansí dixo Virgil. Para significar, que se apagó la llama, Flamma quievit». Pese a su interés, no me ocuparé en este artículo del asunto de la anotación, presumiblemente preparada por González de Salas, aunque tal vez a partir de sugerencias del propio Quevedo. 
se ha insistido siempre en la idea de que epígrafes y subepígrafes eran una creación del editor, un somero repaso de las tradiciones y los modelos en los que pudo inspirarse, así como de la producción poética de escritores contemporáneos, permite afirmar que se trataba de una práctica bastante extendida en las distintas modalidades formales o temáticas, que Quevedo habría podido imitar de igual modo que recreó el tema o la estrofa. De ser así, no habría razón para atribuir en exclusiva a González de Salas, y no al escritor, la redacción de los epígrafes de sus poemas.

Pese a que Persio, Juvenal ${ }^{2}$ u Horacio fueron algunas de las fuentes básicas de la poesía moral de Quevedo, no parece hallarse en los poetas latinos el origen, ya que, por lo general, no la concibieron con títulos. En el caso de Horacio, cabe mencionar no obstante que, aunque las ediciones modernas no acostumbran a incluir epígrafes, sí figuran títulos breves e incluso argumentos previos en una edición de París de 1605, lo que tal vez pruebe el gusto de la época por este tipo de textos ${ }^{3}$. En ella, los cuatro libros de «Carminum» contienen, antes de cada poema, un «argumentum» tras un título breve: «Ad Maecenatem». «Alios aliis rebus duci: se lyricorum versuum studio teneri» (I, Od. I, p. 1); «Ad Augustum», «Deos omneis iratos esse Romanis, ob Cesaris cedem: unam imperii spem in Augusto constitutam» (I, Od. 2, p. 9); «In Virgilium Athenas proficiscentem», «Secundam ei navigationem precatur: deinde occasionem nactus, hominum audaciam detestatur» (I, Od. 3, p. 14); «Ad Romanos», «Corruptos suae aetatis mores infectatur» (III, Od. 6, p. 191). El libro titulado «Epodon» sigue el mismo sistema: «In Menam libertum Pompeii Magni», «Ineius, ex mutata conditione arrogantiam inuehitur» (Od. 4, p. 319). Los libros de sátiras, por su parte, aportan un argumento antes del poema: «Lucilium, veteres comicos Graecos sequutum, mordacem fuisse ait [...] Se alioqui virulentia carere, ac tantum iocosa \& velut paterna quadam castigatione ad deterrendos a vitiis homines uti profitetur» (I, 4, p. 49). Finalmente, los libros de epístolas incorporan títulos y argumentos como el que sigue: «Ad librum suum», «Librum suum compellat, in lucem prodire cupientem: a quo

\footnotetext{
${ }^{2}$ Véase, por ejemplo, una edición conjunta de las sátiras de Juvenal y Persio, en Lugduni, por los hermanos Melchor y Gaspar Trechsel, de 1532; ejemplar de la Biblioteca Nacional de España, con signatura 3/45122. Las 16 sátiras de Juvenal carecen de título, aunque incluyen abundantes anotaciones marginales; lo mismo sucede con las de Persio, cuyos epígrafes se refieren sólo al número del poema.

${ }^{3}$ Véase el volumen con signatura (23585) de la Biblioteca de Menéndez Pelayo: Q. HORATIVS / FLACCVS, / EX FIDE ATQVE AVTORITATE COMPLVRIVM / LIBRORVM MNV-SCRIPTORVM, OPERA DIONYSII LAMBINI [...] PARISIIS, / Apud Bartho-

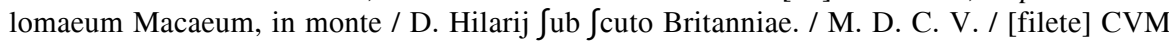
PRIVILEGIO REGIS. Lo mismo sucede en una edición anterior: QVINTI / HORATII / FLACCI VENVSI- / NI POETAE LYRI- / CI POEMATA / OMNIA [...] SALMANTICAE, APVD / Ioannem Mariam à Terranoua. / M. D. LX. El ejemplar consultado, con epígrafes y abundantes notas marginales, está en la Biblioteca Nacional de España, con signatura $\mathrm{R} / 40577$.
} 
eum, propositis, quae impendent [...] aetate, quaedam refert, quae ab eo narrari velit» (I, XX, p. 357).

La práctica se registra en una parte de los libros de epigramas de Marcial, cuyos poemas están precedidos por breves títulos. Así se comprueba en una edición de París, 1607, donde todos los poemas cuentan con epígrafes previos muy breves y están encabezados al menos por el destinatario ${ }^{4}$ : «Barbara Pyramidum sileat miracula Memphis»: «In amphitheatrum Caesaris Epigramma I» (p. 2); «Qualiter in Scythica religatus rupe Prometheus»: «Poena Laureoli VII» (p. 3); «Laeserat infrato leo perfidus ore magistrum»: «De Leone qui gubernatorem offendit» $(\mathrm{p} .4)^{5}$.

Lo mismo sucede en las silvas de Estacio, que, organizadas en cinco libros, incluyen en todos los casos epígrafes de corta extensión, que pudieron dejar huella también en los textos quevedianos de carácter heroico o encomiástico (musa Clío) y fúnebres (Melpómene); recuérdese en tal sentido, sólo como ejemplo, el poema «Somnus», imitado por Quevedo con idéntico título: «El sueño» ${ }^{6}$. Los incluidos en una edición de 1607 muestran que se trataba de una

\footnotetext{
${ }^{4}$ Me baso en la consulta del ejemplar con signatura (11780) de la Biblioteca de Menéndez Pelayo M. VALERII / MARTIALIS / EPIGRAMMATUM / LIBRI XV. / LAURENTII RAMIREZ DE / PRADO Hi pani, Nouis commentarijs / illuStrati. / Cum Indice omnium verborum IOSEPHI LANGLI Caefare- / mont. \& aliis indicibus locupletiffimis. [grabado] PA-

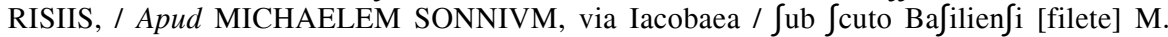
DCVII. / Ex priuilegio Regis.

${ }^{5}$ Otros ejemplos son: «Stellae delicium mei columba»: «Ad Maximum de columba Stellae. IIX» (p. 12); «Vix Celtiberis non tacende gentibus»: «Ad Licianum, de Hispaniae locis. $\mathrm{L} »($ p. 22); «Naeuia sex cyathis septem Iustina bibatur»: «Ad Somnum LXXII» (p. 29); «Si non molestum est teque non piget Scazon»: «Ad Scazontem, de fellatore quodam. XCVII» (p. 35); «Hic, quem videtis gressibus vgis lentum»: «In sictum diuitem. LVII» (p. 57); «Formosam faciem nigro medicamine velas»: «In mulierem deformem. III» (p. 66); «Caesaris alma dies, \& luce sacratior illa»: «De natali Domitiani. I» (p. 91); «Esse quid hoc dicam, viuis quod fama negatur?»: «Ad Regulum de fama Poetarum. X» (p. 121); «Alcide Latio nunc agnoscende tonanti»: «Ad Herculem de eadem statua. LXVII» (p. 244).

${ }^{6}$ Son los siguientes: en el libro I, «Ecus Maximus Domitiani Imp.», «Epithalamion in Stellam et Violentillam», «Villa Tiburtina Manilii Vopisci», «Soteria Rutilii Gallici», «Balneum Claudii Etrusci», «Kalendae Decembres»; en el II, «Glaucias Atedii Melioris delicatus», «Villa Surrentina Pollii Felicis», «Arbor Atedii Melioris», «Psittacus eiusdem», «Leo mansuetus», «Consolatio ad Flavium Ursum de amissione pueri delicati», «Genethliacon Lucani ad Pollam»; en el III, «Hercules Surrentinus Pollii Felicis», «Propempticon Maecio Celeri», «Consolatio ad Claudium Etruscum», «Capilli Flavi Earini», «[Ad uxorem]»; en el IV, «Septimus Decimus Consulatus Imp. Aug. Germanici», «Eucharisticon ad Imp. Aug. Germ. Domitianum», «Via Domitiana», «Epistola ad Vitorium Marcellum», «Ode lyrica ad Septimium Severum», «Hercules Epitrapezios Novi Vindicis», «Ode lyrica ad Vibium Maximum», «Gratulatio ad Iulium Menecraten», «Hendecasyllabi iocosi ad Plotium Grypum»; y en el V, «Epicedion in Priscillam», «Laudes Crispini Vetti Bolani filii», «Epicedion in patrem suum», «Somnus» y «Epicedion in puerum suum». Sigo P. Papini Stati Silvae. Marastoni, A. (ed.). Lipsiae, 1961, en la versión virtual de Bibliotheca Augustana (http://www.hsaugsburg.de/ harsch/Chronologia/Lspost01/Statius/sta_si00.html).
} 
práctica muy extendida: «Balnevm Etrvsci» (I, p. 31); «Surrentivm Pollii» (II, p. 46$)^{7}$.

La posible influencia latina parece detenerse en los autores mencionados, porque los elegíacos — modelo en el caso de la poesía amorosa- no solían anteponer títulos a sus textos poéticos, como se observa en las elegías de Tibulo y Propercio o en los poemas de Catulo; tampoco lo hizo Ovidio en Amores $^{8}$. En la tradición clásica es posible apuntar, no obstante, el precedente de ciertos autores de poemas eróticos griegos, fuente de inspiración también para la materia amorosa: entre los representantes de la lírica arcaica, destacan algunos muy conocidos por Quevedo, como Anacreonte (siglos VIV a. C.) ${ }^{9}$, Píndaro (siglo V a. C.) o Teócrito (s. III a. C.) y sus idilios; pero los títulos breves figuran también, por ejemplo, en Bión (s. II a. C.), en algún lamento fúnebre, o en Mosco (s. II a. C.), así como en ciertos fragmentos helenísticos anónimos ${ }^{10}$. La segunda parte de Antología Palatina, la «Guirnalda de Filipo», refleja una tradición editorial de los epígrafes que en este caso parece remontarse a uno de los copistas del manuscrito palatino (del siglo $\mathrm{X}$ ), quien podría haber añadido lemmata a cada epigrama ${ }^{11}$; aunque tal vez no atribuibles a los autores, la adición de estos lemas tal vez sería indicio de una práctica no infrecuente. También las Anacreónticas - cuya difusión en una edición de H. Estienne (Stephanus), en 1554, causó una gran conmoción en

${ }^{7}$ Añádanse también «Lachrymae Hetrvsci» (III, p. 77); «Risvs Satvrnalitivs ad Plotivm» (IV, p. 116); o «Abscantii in Priscillam Pietas» (V, p. 120). Sigo P. STATII / PAPINII / OPERA QVAE / EXTANT [...] ANTVERPIAE. / Ex Officina Typographica Martini Nutii, / ad insigne duarum Ciconiarum, / M. DC. VII; ejemplar de la Biblioteca Nacional de España, con signatura 2/17575.

${ }^{8}$ Propercio. Élégies. Simone (ed.). Paris: Les Belles Lettres, 2005; Tibulo. Elegías. Hugo Bauzá, Hugo Francisco (ed.). Madrid: CSIC, 1990; Catulo. Poésies. Lafaye, George (ed.). Paris: Les Belles Lettres, 1989; Ovidio: Les Amours. Bornecque, Henri de (ed.). Paris: Les Belles Lettres, 1930.

${ }^{9}$ Recuérdese que Quevedo tradujo a este escritor griego a principios del XVII: dedica su Anacreón en 1609 a Don Pedro Girón, duque de Osuna. La obra se llevó a la imprenta de Sancha en 1794, con el título Anacreón castellano con parafrasi y comentarios por Don Francisco Gómez de Quevedo. Entre las ediciones modernas, puede leerse la de J. M. Blecua: Quevedo, Francisco de. Obra poética (volumen IV). Madrid: Castalia, 1981, pp. 249-344.

${ }^{10}$ Véase, sólo como muestra, Antología de poesía erótica griega. Calvo Martínez, José Luis (ed.). Madrid: Cátedra, 2009. La antología Poetas líricos griegos -Madrid: Librería de Perlado, Páez y Cía., Sucesores de Hernando, 1911- edita sólo sin título los poemas de Safo, Meleagro y Tirteo; contienen epígrafes las odas y epigramas de Anacreonte, así como las composiciones de Erina, Alceo, Alcman, Stesícoro, Ibyco, Simónides, Baquílides, Arquíloco, Alfeo y Pratinas.

${ }^{11}$ Sobre este asunto, consúltese Antología palatina II. La guirnalda de Filipo. Galán Vioque, G. (ed.). Madrid: Gredos, 2004, p. 62. Estos epigramas de la antigüedad fueron recopilados en el siglo I por Filipo de Tesalónica y se remontan, desde esa época, hasta el siglo II a. C. La antología se concibió a imitación de la «Guirlanda de Meleagro», anterior, que engloba composiciones helenísticas; véase Antología palatina (epigramas helenísticos). Fernández-Galiano, Manuel (ed.). Madrid: Gredos, 1978. 
el humanismo europeo- han sido transmitidas con epígrafes breves: «Del vivir sin ambiciones» (VIII, p. 8); «Sobre el joven Batilo» (XVII, p. 18); «Del mismo. Un sueño» (XXX, p. 30); «Canción a la cigarra» (XXXIV, p. 34); «Del avaro» (XXXVI, p. 36); o «A la rosa» (XLIV, p. 43), entre otros ${ }^{12}$.

La introducción de epígrafes en los poemas quevedianos parece inducida preferentemente por la tradición poética italiana. Si bien es cierto que Dante $^{13}$, Petrarca ${ }^{14}$ o Pietro Bembo ${ }^{15}$ no los incluyeron en sus Rime, sí lo hicieron Matteo Maria Boyardo, Torquato Tasso, Luigi Groto y Giovanni Battista Marino - así como los poetas «marinistas»-, autores que ejercieron una notable influencia en la poesía amorosa quevediana y cuyos epígrafes guardan una gran semejanza con los de Quevedo en sus distintas formulaciones: desde los concebidos como mera dedicatoria hasta los aclaratorios de circunstancias anecdóticas o históricas.

Boyardo, cuyo Orlando innamorato sirvió de modelo básico para el Poema heroico de las necedades y locuras de Orlando enamorado de Quevedo, incluyó en su Amorum libri tres —con título ovidiano y estructura de «canzoniere»— abundantes epígrafes latinos en sonetos, canciones y madrigales, aunque no de forma sistemática. Algunos se refieren a la propia estrofa, y la mayoría son muy breves, como «Ad Guidonem Scaiolam» (p. 263), «Ad Amorem interogatio» (p. 272) o «Item ad eundem» (p. 274) ${ }^{16}$. Luigi Groto, cuyos madrigales imitó Quevedo en algunos de sus poemas amorosos, no incorpora epígrafes en los sonetos de sus Rime en una edición de su poesía de finales del XVI, pero sí en otras formas estróficas, por ejemplo, «Incendio del Tempio di Diana Efesia» o «Ruggier, pri c'hebbe liberata Angelica» (p. 139) ${ }^{17}$. Sin embargo, la incorporación de títulos es ya sistemática también en los sonetos

${ }^{12}$ Recuérdese, más allá de los problemas textuales y las falsas atribuciones que rodean la figura de Anacreonte de Teos, que Quevedo se interesó por su obra hasta el punto de ofrecer una traducción en su Anacreón castellano, de la que existe testimonio manuscrito en la Biblioteca Nacional de España, con signatura MSS/17529. Sobre la difusión de las Anacreónticas, véase Brioso Sánchez, M. (intr.). Madrid: CSIC, 1981, pp. IX-LXXXIX; las citas proceden de esta edición.

${ }^{13}$ Sigo Rime. Robertis, Domenico de (ed.). Fireze: Casa Editrice Le Lettere, 2002.

${ }^{14}$ Petrarca, Francesco. Cancionero. Cortines, Jacobo de (ed.). Madrid: Cátedra, 2006, 2 vols.

${ }^{15}$ En el ejemplar de las Rimas de Bembo consultado, editado en 1569, con signatura (715) de la Biblioteca de Menéndez Pelayo, los poemas, de estrofas diversas y carácter amoroso, carecen de epígrafes; tampoco los llevan las rimas a la muerte de su hermano. RIME / DI M. PIETRO / BEMBO. / TRATTE DAL PROPRIO / ORIGINAL DI LVI. / ALLE QVALIS'E AGGIVNTA VNA / taula di tutte le definenze fotto le lettere / uocali infieme co' uer i interi; / [figura con volutas] CON OGNI ACCVRATEZZA / corrette \& riuedute per Thoma 50 Porcachi. / [grabado centrado con un escudo IN VINEGIA APRESSO GABRIEL / GIOLITO DE'FERRARI. / M D L X I X.

${ }^{16}$ Boiardo, Matteo Maria. Amorum libri tres. Torino: Giulio Einaudi Editore, 1998.

${ }^{17}$ Las citas de Groto proceden del ejemplar de la edición de Delle Rime, Venecia, 1587, que se guarda en la Biblioteca de Menéndez Pelayo, con signatura 8446. 
en ediciones posteriores, por ejemplo en la de Venecia de 1610, en la cual figuran en todo tipo de composiciones y en los tres libros que la configuran ${ }^{18}$. Como muestra de estos «argomenti» — que son muy breves, a veces se reducen a una palabra y casi nunca ocupan más de una línea - sirvan los siguientes: «La Donna sua è mobile» (I, f. 27); «Amore morto \& viuo» (I, f. 31); «Ragione contra Amore» (I, f. 35); «Ricetta per farsi amare» (II, f. 8); «Tormenti amorosi» (II, f. 46v); «Foco e Ghiaccio» (II, p. 53v) $)^{19}$.

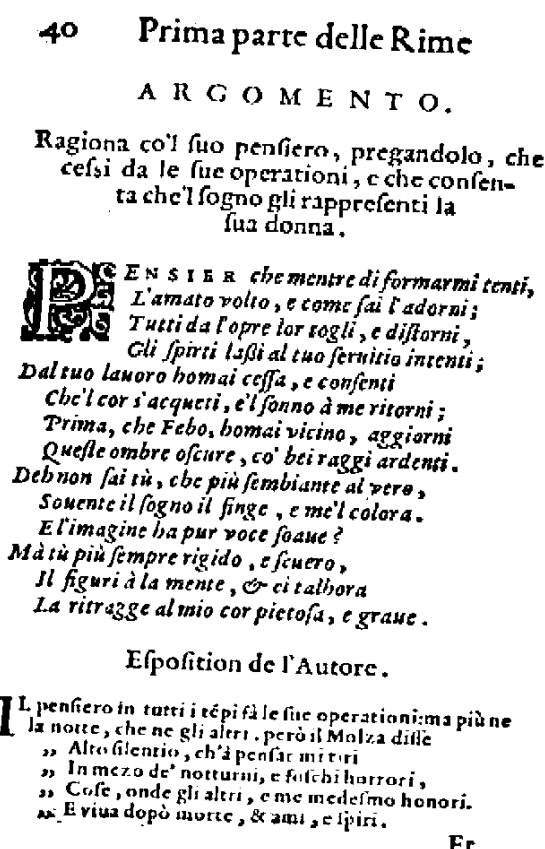

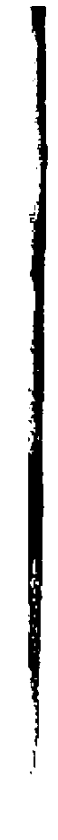

Del Sig. Torquato Ta fo. 4 t

Ee in quella parec de la nutte, che I l atini chismano Con cuhia, yi amant fomparndi , figh suno altetruolamen-

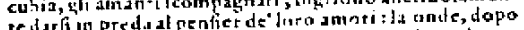

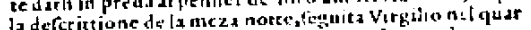

code l'Enedela fua narrations, con quelle patcle.

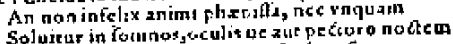

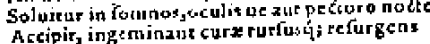
S.ruir Amor.

Però î́ Potra rel maedefimo tempo,prega il futs penfieto,

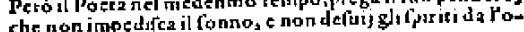
perationinaturali.

perationinatural thatione de la fua dunna.

CHE L CORSACQQVETI.

$C H L^{2} L C O R S A C Q V$ Co Terchit fonno il quale, come dice Euftatio nel primo do l'Ethica, corio de l'anima, lesa d fenfo com atre nel cuo-

riori.

PRIMA, CHE Febi B Dimoltra, che ne pentielihacom. la onde era homai vicenal'alba.

QYESTE OMBRE OSCVRE.

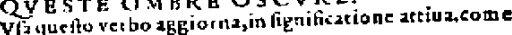
Ysò il Bembo

"Ell Sol, che le mie notti aggiorna.

funo. NOY SAI TV CHEPIV SEMBIANTB DL VERO.

Para

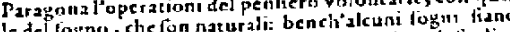
le del togno, che fon naturatotele, ò duuni, i quatl togliono apparirci.

ARCO-

LÁmina 2. Edición de las Rime de T. Tasso de 1592.

Tasso «Invita gli occhi a rimirar la sua donna» (IX, p. 651), «Ragiona col suo pensiero pregandolo che cessi da le sue operazioni e che consenta che'l sogno gli rappresenti la sua donna» (XVIII, p. 655) ${ }^{20}$, «Accenna la cagione

${ }^{18}$ Sigo un ejemplar impreso por Ambrossio Dei, que se conserva en la Biblioteca Nacional de España, con signatura 3/48399.

${ }^{19}$ Añádanse otros, entre los muchos posibles: «Al Sole volendo tornare, alla sua Donna» (II, f. 4v); «Alla sua Donna, che li haueua scaldato le mani» (III, f. 15); «All'Aurora» (III, f. 21).

${ }^{20}$ Como se observa en la lámina 2, la edición de 1592 de la poesía de Tasso incluye «argumentos» equivalentes a los epígrafes de la poesía de Quevedo; además, existe una «exposición» del autor que cumple las funciones de una anotación filológica. 
per la quale egli, lontano de la sua donna, non sol conserva ma accresce l'amore» (XLII, p. 667), «Mostra di sperare che'l tempo debba far le sue vendette contro la sua donna, in guisa ch'ella ne la vecchiezza debba pentirsi d'averlo sprezzato a desiderar d'essere celebrata da lui» (XLVI, p. 669) o «Assomiglia la signora Laura a l'Aurora, bench'ella andasse vestita di nero» (III, p. 690). No obstante, su ejemplo también podría haberse dejado sentir en poemas funerales o encomiásticos, que Tasso titula, por ejemplo, «Sul ritratto di donna Irene da Spilimbergo, dopo la sua morte» (II, p. 755) o, a propósito de las circunstancias de la composición, «Venendo l'autore di Bologna in Padova fu raccolto ne l'Academia de gli Eterei che si ragunava in casa del signor Scipione Gonzaga, suo particolar signore e protettore...» (IV, p. 756 ${ }^{21}$ Interesa destacar que la primera y segunda parte de Delle Rime, en la edición de Brescia, 1592, incluye, además de anotación sistemática del autor, un «argomento» que precede a todos los sonetos, canciones, estancias, «ballatas», madrigales y sextinas ${ }^{22}$.

En la misma línea, G. B. Marino, en Lira, incluye poemas cuyo título casi siempre breve apunta al tema, muchas veces relacionado con un momento intrascendente de la vida de una dama, tan próximos a algunos de la musa Erato $^{23}$ : «Silenzio che parla» (VI, p. 211), «Mentre la sua donna si specchiava» (I, p. 213), «Al sonno» (V, p. 215), «Per un anello d'oro donatogli dalla sua donna» (VIII, p. 217), «Per una rosa caduta di bocca alla sua ninfa» (XIX, p. 223). Sus epígrafes preceden también a poemas de carácter funeral o de elogio: «Alla sepoltura di Giacopo Sannazaro ch'è in Mergellina presso Napoli» (XXIX, p. 229), «Alla citta de Venezia» (XXXIII, p. 232) o «Nel dì natale del signor duca di Savoia» (XXXIV, p. 232) ${ }^{24}$.

\footnotetext{
${ }^{21}$ Cito por Tasso, Torquato. Poesie. Milano-Roma: Rizzoli \& C. Editori, 1934.

${ }^{22}$ El ejemplar consultado procede de la Biblioteca Nacional de España y tiene signatura $3 / 26542$.

${ }^{23}$ Véase la lámina 3, para apreciar el diseño editorial de la edición de las Rime de Marino.

${ }^{24}$ Las citas proceden de Opere scelte di Giovanni Battista Marino e dei marinisti. Getto, Giovanni (ed.). vol. I. Torino: Unione Tipografico-Editrice Torinese, 1976. La edición de las Rime de Marino de Venecia, 1609, ejemplar con signatura (1379) de la Biblioteca de Menéndez Pelayo, muestra que los sonetos de la primera parte - con portada RIME / DI / GIO. BATTISTA / MARINO, / Amorose, Lugubri, / Marittime, Morali, / / Boscareccie, Sacre, / Heroiche, Varie. [...] IN VENETIA M. D.C.VIIII / APRESSO BERNARDO GIVNTI ET GIO. BAT.A CIOTTI.- carecen de epígrafes, que en cambio sí figuran en la segunda parte - con portada propia: RIME / DEL / MARINO, / SECONDA / Parte. / Madrigali, e Canzoni. [...] IN VENETIA M. D.C.VIIII / APRESSO BERNARDO GIVNTI ET GIO. BAT.A CIOTTI.- , cuyos preliminares están fechados en 1602 como los de la primera. Por su parte, la edición de La Lira, en Venecia, 1616, ejemplar con signatura (1384) de la Biblioteca de Menéndez Pelayo -LA LIRA, / RIME / DEL / CAVALIER / MARINO. / [...] IN VENETIA / Apresso Gio. Batt. Ciotti. M.D.C.XVI- incluye epígrafes en sonetos y otras estrofas de sus distintos apartados, titulados «Amori», «Lodi», «Lagrime» y «Divotione», cuyo equivalente serían en España los poemas amorosos, encomiásticos, fúnebres y religiosos.
} 


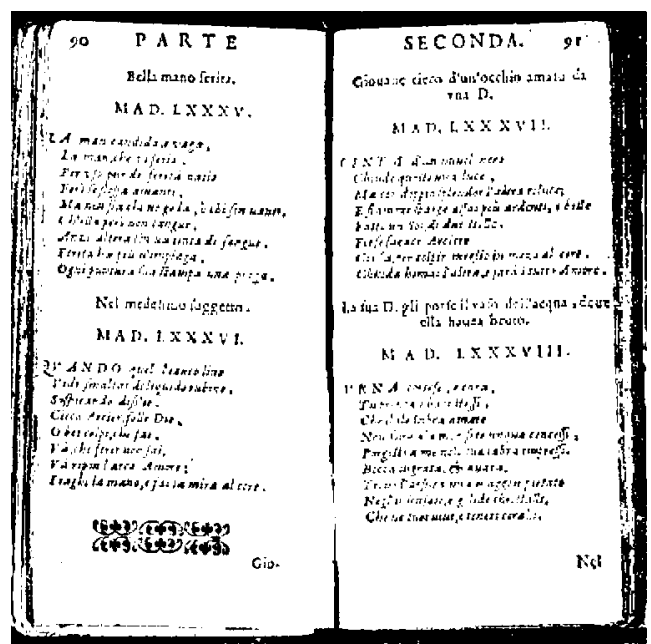

LÁmina 3. Edición de las Rime de Marino de principios del XVII.

Junto a los posibles modelos grecolatinos e italianos, la tradición poética española del Siglo de Oro ofrece abundantes ejemplos de difusión de los poemas con breves epígrafes indicativos de su contenido. Para el caso de la materia moral, puede recordarse la poesía original de Luis de León, precedida de títulos muy cortos o dedicatorias, como se observa en la edición de Quevedo, de Milán en 1631, donde abundan títulos a la manera de dedicatorias, las traducciones de autores clásicos como Virgilio carecen de título, y las de salmos bíblicos van precedidas de un título latino que alude a la fuente, próximo a los epígrafes de Polimnia ${ }^{25}$. Sirvan como ejemplo los siguientes casos: «Noche serena, a D. Oloarte», «Cuando contemplo el cielo» (p. 18); «Las Serinas a Cherinto», «No te engañe el dorado» (p. 21); «A Felipe Ruiz», «Cuándo será que pueda» (p. 23); «Al licenciado Juan de Grial», «Recoge ya el seno» (p. 26); «A Felipe Ruiz», «Qué vale cuanto ve» (p. 27); «De la vida del cielo», «Alma región luciente» (p. 30); «Al apartamiento», «Oh, ya seguro puerto» (p. 31); «A don Pedro Portocarrero», «No siempre es poderosa» (p. 34); «Contra un juez avaro», «Aunque en ricos montones» (p. 35) ${ }^{26}$. Obsérvese en algún caso la cercanía respecto a los epígrafes de Clío o Melpómene.

${ }^{25}$ Los datos proceden del ejemplar con signatura (661) de la Biblioteca de Menéndez Pelayo: OBRAS PROPIAS / y Traducciones, con la parafrafi / de Algunos P falmos de Dauid


dela / Gloriosa Orden del grande / Do tor y Patriarca Sant / Agustin. / En Madrid efte Año 1631. las hizo Imprimir / Don Francifco de Queuedo Villegas. / Illu- / Jstrandolas con la dire $\xi$ tion prote $\xi$ tion / y nombre del Excelentifs. Conde / Duque Gran Canciller / \&c. / EN MILAN. / Por Phelippe Guifolfi. Año 1631. / Con licencia de los Superiores.

${ }^{26}$ Añádanse los siguientes casos: «En la ascensión», «Y dejas pastor santo» (p. 39); «A todos los santos», «Qué santo? O qué gloriosa» (p. 40); «Del mundo y su vanidad», «Los que tenéis en tanto» (p. 58); «Del conocimiento de sí mismo. Canción», «En el profundo del abismo estaba» (p. 66); «Canción al nacimiento de la hija del marqués de Alcañices», «Inspira nuevo canto» (p. 72); «A don Pedro Portocarrero», «Virtud hija del cielo» (p. 4); «A Francisco Salinas», «El aire se serena» (p. 6); «A Felipe Ruiz de la Avaricia», «En vano el mar fatiga» (p. 10); «Profecía del Tajo», «Holgaba el rey Rodrigo» (p. 15); «Epitafio al túmulo del príncipe don Carlos», «Aquí yacen de Carlos los despojos» (p. 75); «Canción a la muerte del mismo», «Quien viere el suntuoso» (p. 76). 
Piénsese asimismo en los poemas de Leonardo y Bartolomé Leonardo de Argensola, que en la edición de 1634 a cargo del hijo del primero, Gabriel Leonardo de Albión, carecen de epígrafes en el cuerpo de la obra, pero tales aclaraciones, sobre el contexto, el destinatario o el tema, se incluyen en los índices de ambos autores con independencia del tema o el tipo de estrofa utilizado $^{27}$. Así, en el de las Rimas de Lupercio, ff. [12-15], se recogen por ejemplo: soneto «A aquel rayo de Marte acelerado»: «Compara la duda en que le puso la grandeza de la empresa que amor le proponía y la perseverancia con que la prosiguió después de resuelto con la duda que César tuvo de acometer el apoderarse del imperio, y con la constancia con que ejecutó su resolución» (f. [12]); tercetos «Aquí donde en Afranio y en Petreyo»: «Esta carta se escribió a don Juan de Albión desde Lérida, ciudad de Cataluña, en donde se hallaba el autor en la sazón, en que vino de Alemaña la serenísima emperatriz María, cuyo secretario fue después» f. [12]; canción «Aquellos dos cristales transparentes»: «Muestra sentimiento de tener causa para sospechar que un gran amigo suyo se había entibiado en su amistad» ${ }^{28}$. En el índice de las obras de Bartolomé, ff. K3-K[8], el criterio es idéntico: canción «Apenas hizo la razón ausencia»: «Alegoría con que pinta los efectos que causa en el nimo del intentar el apetito prevalecer contra la razón», f. $\mathrm{K}_{3}$; tercetos «A la fuente anheló de eterna vida»: «Traducción del himno Ad perenniso vitae fontem, cuyo autor fue el cardenal Pedro Damiano», f. $\mathrm{K}_{4}$; soneto «Bílbilis, aunque el Dios que nació en Delos»: «Habla con la ciudad de Calatayud», f. $\mathrm{K}_{6}$; soneto «Di, Eríne, aunque a Pitágoras leyendo»: «La gracia de este soneto consiste en aplicar a una mujer el precepto de abstenerse de las habas que Pitágoras imponía a sus discípulos», f. $\mathrm{K}_{4}$; décima «No induce necesidad»: «A esta décima dio ocasión una plática que tuvo el autor con el doctor Gaspar Ram, arcipreste de Daroca, en la santa iglesia de Zaragoza [...] In manibus tuis fortes meae», f. $\mathrm{K}_{6}$.

Aunque ciertos autores manejados indudablemente por Quevedo no redactaron epígrafes para sus poemas —es el caso de Garcilaso de la Vega, Juan Boscán o Francisco de la Torre- o lo hicieron muy raramente, a la manera de mera dedicatoria, como Fernando de Herrera $^{29}$, es posible apuntar ciertas

${ }^{27}$ La información procede del volumen con signatura (1284) de la Biblioteca de Menéndez Pelayo: RIMAS / DE LUPERCIO, / I DEL DOTOR / BARTOLOME / LEONARDO / DE ARGENSOLA. / [filigrana] CON LICENCIA, I PREVILEGIO / De la Corona de Caftilla, i Aragon./ EN ZARAGOZA, / En el Hofpital Real, i General de / nueftra Señora de Gracia, / Año 1634.

${ }^{28}$ También por ejemplo en los sonetos «Quién es el tierno mozo que entre rosas»: «Traducción de la Ode quinta del libro I. Carminum de Horacio, Quis multa gracilis» f. [14v]; o «Viento cruel, cruel y avaro velo»: «Escribiose este soneto con ocasión de haber el viento moviendo una toca de una señora cubiértole el rostro» f. [15].

${ }^{29}$ Véase la edición de los Versos de Fernando de Herrera, de 1619, que Quevedo leyó y anotó, como se observa en el ejemplar custodiado en la Biblioteca del Seminario Diocesano de Vitoria-Gasteiz, con signatura Ms. 179. 
coincidencias con autores en algún caso contemporáneos y que, en la mayoría de los casos, parecen relacionadas más con cuestiones de índole genérica que temática. Los sonetos de Góngora tienen en muchos casos títulos, por lo general breves, como se observa en los sacros (próximos a Urania), los heroicos (Clío), los morales (Polimnia), los fúnebres (Melpómene), así como algunos de los amorosos (Erato) y burlescos (Talía). Como sucede en el caso de Quevedo, las letrillas, estrofa en la que Góngora fue modelo indiscutido, carecen de títulos en sus tipos sacro, satírico, burlesco y lírico; lo mismo sucede con los romances, que tampoco los tienen en su vertiente sacra, amorora o satírico-burlesca, aunque sí en la modalidad fúnebre ${ }^{30}$. Cabe recordar asimismo, el caso de las Rimas de Tomé de Burguillos, de Lope de Vega, publicadas en 1634 con aprobación de Quevedo, cuyas composiciones burlescas contienen títulos breves equiparables a los que existen en ciertos poemas de la musa VI del Parnaso quevediano: «Espíritus sanguíneos vaporosos», «Dice cómo se engendra amor, hablando como filósofo»; «En un arco de perlas una flecha», «A un palillo que tenía una dama en la boca»; «Aura süave y mansa, que respiras», "Alaba el poeta lo más esencial de la hermosura sin ser parte de la armonía de las faciones» ${ }^{31}$. Y, para el caso de un subgénero encauzado por Quevedo hacia el ámbito de la poesía culta, téngase en cuenta el ejemplo de los autores de poesía germanesca de los siglos XVI y XVII, cuyos títulos podrían justificar la presencia de epígrafes en los poemas de este tipo contenidos en la musa V, las jácaras y bailes. Los quevedianos se aproximan mucho a los de los Romances de germanía de varios autores compilados por Juan Hidalgo, en Barcelona, 1609: «Perotudo» (p. 55), con la aclaración «Este romance es el primero que se compuso en esta lengua, y advierta el lector que se llama baile porque trata del ladrón que ahorcaron»; «Romance de la descripción de la vida airada« (p. 67); «Romance de la venganza de Cantarote» (p. 78); «Romance de la vida y muerte de Maladros» (p. 83). Los epígrafes que figuran en poemas germanescos más tempranos, del siglo XVI, como los de Reynosa, son más extensos y detallan más el argumento que los de Quevedo: «Gracioso razonamiento en que se introducen dos rufianes: el uno preguntando, el otro respondiendo en germanía de sus vidas, arte de vivir; cuando viene un alguacil, los cuales, como le vieron, fueron huyendo, no pararon hasta el burdel a casa de sus amigas [...] así acaba» (p. 7) ${ }^{32}$.

${ }^{30}$ Tomo los datos de la edición facsímil del «manuscrito Chacón» (Alicante, 2005), de la Biblioteca Virtual Miguel de Cervantes, Obras de D. Luis de Góngora, tomos I, II y III, custodiado en la Biblioteca Nacional de España, con signatura Res. 45.

${ }^{31}$ Cito por Rimas humanas y divinas del licenciado Tomé de Burguillos, en Obras poéticas. J. M. Blecua, J.M. (ed.). Barcelona: Planeta, 1983.

${ }^{32}$ En otro caso, «comienza un razonamiento por coplas en que se contrahace la germanía y fieros de los rufianes y las mujeres del partido, de un rufián llamado Cortaviento, y ella Catalina Torres Altas...» (p. 3). Todas las citas, modernizadas, proceden de Poesías germanescas. Hill, John M. (ed.). Bloomington: Indiana University, 1945. 


\section{EPÍGRAFES EN POEMAS AUTÓGRAFOS Y COLECCIONES TEMPRANAS}

Sin propósito de exhaustividad, se pretende ahora indagar en posibles versiones tempranas de los poemas quevedianos, para saber si éstas incluían o no epígrafes; su presencia en antologías manuscritas o impresas previas a la muerte de Quevedo y, por tanto, ajenas a la intervención póstuma de González de Salas en El Parnaso, sería indicio de que tal vez el escritor habría concebido sus composiciones con este «título» inicial, lo que no obsta para que el editor los hubiese podido manipular en casos concretos. También resulta de interés un análisis semejante en el caso de los poemas editados por Aldrete e incluso en aquellos que, habiéndose divulgado en vida del autor, nunca llegaron a incorporarse a la edición póstuma de su poesía.

Aunque es cierto que muchos códices manuscritos no pueden ser datados con seguridad, sino sólo en referencia a su siglo (el XVII), destacan aquellos casos referidos a ciertas recopilaciones tempranas anteriores a Parnaso y Tres musas, en las cuales el epígrafe ya se encontraba, con formulaciones equivalentes o variantes: Flores de poetas ilustres (1605), Segunda parte de Flores (1611), Cancionero de 1628, Cancionero antequerano (1627-1628) o Maravillas del Parnaso (1637), por citar sólo aquellos cuya fecha no plantea duda. A ellos se suman los contenidos en obras, propias o ajenas, publicadas en la tercera o cuarta década del siglo, o, especialmente, los autógrafos de un soneto moral que incluye un epígrafe de mano del propio Quevedo y los incluidos en una serie de 27 silvas, 17 autógrafas y el resto corregidas por él ${ }^{33}$.

En lo que atañe al asunto de los autógrafos, sorprende que las silvas contenidas en el manuscrito de Nápoles figuren con título, lo que constituye un indicio bastante elocuente de que Quevedo habría imaginado sus poemas con epígrafe ${ }^{34}$; de ser así, de él procederían tal vez mayoritariamente los que finalmente publicaron González de Salas y, más adelante, Pedro Aldrete ${ }^{35}$. Por su interés, se relacionan a continuación:

${ }^{33}$ Los textos del manuscrito de Nápoles, con signatura XIV.E.46, pudieron haberse escrito durante la estancia de Quevedo en Italia. Sobre este asunto, véanse Ettinghausen [1972b:218] y Rey [1999:16-17]. Este último, citando a Rocha de Sigler, menciona que el códice podría ser posterior a 1625 .

${ }^{34} \mathrm{He}$ consultado la copia del manuscrito de Nápoles que obra en poder de Alfonso Rey, de quien procede la foliación indicada, resultado de su examen directo del códice. Registro las ligeras discrepancias que he encontrado en los epígrafes de los poemas, respecto a los datos que ofrece Blecua, cuya edición sigo en los abundantes casos en que el manuscrito resulta ilegible.

${ }^{35}$ El estudio de Rey [2006] revela que Quevedo puso especial cuidado en la configuración de su corpus de silvas, tal vez con la idea de dedicar un libro a este género poético, a la manera de Estacio. Piénsese que también figuran en las composiciones, un total de siete, compiladas en la Segunda parte de Flores de poetas ilustres de Calderón, de 1611, como señala Rey [2006:260-261]. 


\begin{tabular}{|c|c|}
\hline EPÍGRAFE EN «NÁPOLES》 & EPIGRAFE EN PARNASO \\
\hline $\begin{array}{l}\text { «Silva 20. El escarmiento en la soledad, al } \\
\text { desengaño en poblado» (f. } 117 \mathrm{v})\end{array}$ & «El escarmiento» \\
\hline «Silva [12] A la soberbia» (f. 162) ${ }^{36}$ & «La soberbia» \\
\hline «Silva 7. La mina» (f. 148v) & «A una mina» \\
\hline «[xxxx] Túmulo a una mariposa» (f. 152) & «Túmulo de la mariposa» \\
\hline $\begin{array}{l}\text { «Silva 1. A una tórtola que se halló muerta sin } \\
\text { herida» (f. 137) }\end{array}$ & $\begin{array}{l}\text { «Exequias a una tórtola que se quejaba viuda, y } \\
\text { después se halló muerta» }\end{array}$ \\
\hline «Silva 25 [26]. Lamentación» (f. 125v) & «Lamentación amorosa» \\
\hline «Silva 14. Contraposición amorosa» & «Contraposición amorosa» \\
\hline $\begin{array}{l}\text { «Silva 13. Exclama a Júpiter contra unos ojos a } \\
\text { quien el mismo Júpiter teme» }\end{array}$ & $\begin{array}{l}\text { «xclama a Júpiter contra unos ojos a quien el } \\
\text { mismo Júpiter teme» }\end{array}$ \\
\hline «Silva 24. Testamento amoroso» (f. 123v) & «Hace últimamente su testamento» \\
\hline «Amante que muere. Silva 22»(f. 121) & «Lamenta su muerte y hace epitafio a su sepulcro» \\
\hline
\end{tabular}

\begin{tabular}{|c|c|}
\hline EPIGRAFE EN «NÁPOLES» & EPIGRAFE EN LAS TRES MUSAS \\
\hline «Silva 9. «Roma antigua» (f. 152v) & «Silva 13. A Roma antigua y moderna» \\
\hline $\begin{array}{l}\text { «Exhortación a una nave nueva al entrar en el } \\
\text { agua» }\end{array}$ & $\begin{array}{l}\text { «Exhortación a una nave nueva al entrar en el } \\
\text { agua» }\end{array}$ \\
\hline «Silva [28] A un reloj de arena» (f. 150) & «El reloj de arena» \\
\hline $\begin{array}{l}\text { «Silva 19. A los huesos de un rey que en un } \\
\text { túmulo, ya gastado el epitafio, estaban, y sólo por } \\
\text { una corona que estaba dentro se conoció su } \\
\text { dignidad» }\end{array}$ & $\begin{array}{l}\text { "A los huesos de un rey que se hallaron en un } \\
\text { sepulcro, ignorándose, y se conoció por los } \\
\text { pedazos de una corona» }\end{array}$ \\
\hline «A la calamidad. Silva $23 »($ f. $121 \mathrm{v})$ & «Alaba la calamidad» \\
\hline «Silva 18. Al inventor de [la] artillería» (f. 159) & «Execración contra el inventor de la artillería» \\
\hline «Poema heroico a Cristo resucitado» & «Poema heroico a Cristo resucitado» \\
\hline $\begin{array}{l}\text { «Silva }\left[3^{a}\right] \ll A \text { un ramo, desgajado con el peso de } \\
\text { su fruta» (f. 139v) }\end{array}$ & $\begin{array}{l}\text { «A un ramo que se desgajó con el peso de su } \\
\text { fruta» }\end{array}$ \\
\hline «Silva $4^{\mathrm{a}}$ A una fuente» (f. 140v) & «Silva. El arroyo» \\
\hline «19. El pincel» (f. 115) & «Silva 25. El pincel» \\
\hline $\begin{array}{l}\text { «A don Jerónimo de Mata en el libro de "Las } \\
\text { tristezas de Amarilis", insigne músico de laúd. } \\
\text { Silva } 15 »\end{array}$ & $\begin{array}{l}\text { «A don Jerónimo de Mata en el libro de "Las } \\
\text { tristezas de Amarilis"» }\end{array}$ \\
\hline «Silva 6. Al sueño» & «El sueño» \\
\hline «XII silva. A unos hechizos amorosos» & «Farmaceutria o medicamentos enamorados» \\
\hline «Silva $4^{\mathrm{a}}$ A una fuente» (f. 140v) & $\begin{array}{l}\text { «Amante que vuelve a ver la fuente de donde se } \\
\text { ausentó»" }\end{array}$ \\
\hline «Silva doze. 15. Himno a las estrellas» (f. 156) & «Silva 16. Himno a las estrellas» \\
\hline $\begin{array}{l}\text { «Silva 16. Al cerro altísimo que de la forma en que } \\
\text { remata llaman Yelmo en la Sierra de Sigura, donde } \\
\text { nasce Guadalquivir y otros ríos» (f. } 157 \mathrm{v})\end{array}$ & $\begin{array}{l}\text { «Silva } 17 . \text { El yelmo de Segura de la Sierra, monte } \\
\text { muy alto al austro» }\end{array}$ \\
\hline «Silva 26. Lamentación» (f. 125v) & «Silva 20. Ansia de amante porfiado» \\
\hline
\end{tabular}

${ }^{36}$ Este título se sitúa encima de otro tachado pero aún legible: «el desengaño en la soledad para el escarmiento en poblado». 
En cuanto a las antologías de principios de siglo, Flores de poetas ilustres es significativa, por temprana (los textos debieron de compilarse antes de 1603, fecha de las aprobaciones) y porque Quevedo destaca entre sus contemporáneos por incluir de modo sistemático epígrafes infrecuentes en composiciones de Lupercio Leonardo de Argensola, Pedro Espinosa, Luis de Góngora, Lope de Vega, Juan de Valdés, Juan de Arguijo, Baltasar del Alcázar, Luis Barahona de Soto y otros. Son los que siguen: «Delante del sol venía», «De Dafne y Apolo. Fábula»; «Oye la voz de un hombre que te canta», «A una dama hermosa, rota y remendada»; «No os espantéis, señora Notomía», «A una mujer flaca»; «Yace en esta tierra fría», «A Celestina»; «La voluntad de Dios por grillos tienes», «A la mar» ${ }^{37}$; «Aquí yace Mosén Diego», «A un cristiano nuevo, junto al altar de San Antón»; «No sé a cuál crea de las dos», «A una vieja que traía una muerte de oro»; «Mi madre tuve entre ásperas montañas», «A la primera nave del mundo». Por tanto, de 17 poemas de Quevedo, 8 tienen epígrafe y, entre los que carecen de él, 3 son letrillas, que nunca lo llevan en la edición póstuma. El dato, llamativo en sí, es más sorprendente si se tiene en cuenta que, de una antología integrada por 248 composiciones, sólo 30 lo incorporan, 8 de ellos de autoría quevediana. Téngase en cuenta, además, que la mayoría de los que no están en poemas de Quevedo son meras dedicatorias a un personaje histórico o religioso, como en los textos compilados al final de Flores, y no aclaraciones temáticas o circunstanciales: «A san Acacio», «A san Hermenegildo, rey de Sevilla», «A don Cristóbal de Mora», «Al rey don Felipe, nuestro señor», etc. ${ }^{38}$.

Añádase a ello que también los siete poemas de Quevedo reproducidos en la Segunda parte de Flores (1611) se copian con un título como encabezamiento: «Farmaceutria», «A una nave», «A una fuente», «Reloj de arena», «Al sueño», «A una mina», «A la primavera» ${ }^{39}$. Tal vez sea posible relacionar el esmero con que el escritor parece haber cuidado determinados grupos de poemas, como mostró Rey [1999:16] a propósito de las silvas y su inserción parcial en este cancionero, con la propia redacción de epígrafes.

El análisis comparativo muestra, asimismo, que la incorporación de epígrafes es una práctica temprana en la trayectoria literaria de Quevedo, como lo confirman los ejemplos incluidos en colecciones de comienzos del XVII,

${ }^{37}$ Como ya apuntó Rey [1999:16], Pedro Espinosa se ve obligado a aclarar, en la tabla final de ingenios representados en el volumen, que en este soneto «es A la mar el sujeto, y falta el título» (p. 765). Tal aclaración muestra que tal vez a Quevedo el olvido del epígrafe no le pareció cuestión baladí, sino merecedora de enmienda.

${ }^{38}$ Las citas proceden de Espinosa, Pedro. Primera parte de Flores de poetas ilustres de España. Sarno, Inoria Pepe y José-María Reyes Cano (eds.). Madrid: Cátedra, 2006.

${ }^{39}$ Véase Segunda parte de las Flores de poetas ilustres de España ordenada por Juan Antonio Calderón. Anotación de Juan Quirós de los Ríos y Francisco Rodríguez Marín. Sevilla: Imprenta de E. Rasco, 1896. Los poemas de Quevedo, editados en el vol. I, se agrupan entre las páginas 214 y 227, con numeración 144 a 150 y en el orden en que se relacionan. 
pero no en la edición póstuma: «No sé a cuál crea de las dos», «A una vieja que traía una muerte de oro» (Flores y Cancionero de 1628; Obras de Juan de Tassis, 1635); «Yacen de un home en esta piedra fría». «A un médico» (Flores y Cancionero de 1628), entre otros.

\section{LOS EPÍGRAFES DE PARNASO}

El primer problema textual que plantea la poesía de Quevedo consiste en deslindar su autenticidad frente a las posibles manipulaciones de su editor póstumo, González de Salas. Mientras unos críticos tienden a pensar que éste se permitió diversas libertades con los textos de su amigo, otros sostienen que fue respetuoso con los originales, limitándose a ilustrarlos por medio de algunos epígrafes y notas explicativas ${ }^{40}$. No es propósito del presente artículo entrar en el examen de los poemas propiamente dichos, sino, más modestamente, en sus paratextos, y, de modo más concreto, en sus epígrafes. Su análisis puede arrojar alguna luz sobre el modo en que Quevedo escribía poesía, y, complementariamente, ayudarnos a valorar la autoridad textual de El Parnaso español y Las tres musas últimas.

Tomando como punto de partida las declaraciones de González de Salas y los trabajos que se han hecho sobre este asunto - a propósito del conjunto de Parnaso como Crosby [1966] y Schwartz-Arellano [1989], sobre la poesía moral [Rey, 1999] o la segunda sección de la poesía amorosa, «Canta sola a Lisi», [Fernández-Mosquera, 1999]—, en este apartado del artículo analizaré los epígrafes de las ediciones póstumas de 1648 y 1670, en relación con los de la tradición clásica y áurea que Quevedo imitó. Una vez apuntadas las posibles fuentes que pudieron haber influido en la decisión (del autor o del editor) de incluirlos en la colección impresa, y revisados los epígrafes que figuraban en autógrafos y antologías tempranas, me propongo compararlos con los que preceden a los poemas en las seis musas del Parnaso, no siempre sistemáticos y alguna vez prolijos, y en las tres de la edición de Aldrete: describiré su tipología y su relación con los textos a los que se refieren y analizaré posibles indicios de su hipotética redacción por parte de Quevedo. Ello no obsta para que reconozca la dificultad de alcanzar conclusiones claras sobre la autenticidad de la atribución a González de Salas y la posible intervención de Quevedo en la escritura de epígrafes.

\footnotetext{
${ }^{40}$ Aunque Aldrete atribuyó los epígrafes a Quevedo, J. O. Crosby [1966:111; 1967:40; 1973:631] argumentó que parecen haberse debido a González de Salas, como también lo hicieron A. Egido [1982:232] y Schwartz-Arellano [1989:29]; parece asumir tal hipótesis, aunque con matices y centrado en el caso de «Canta sola a Lisi», Fernández-Mosquera [1999:342]. J. M. Blecua [1969:XXXVIII] apuntó la posible combinación entre una intervención inicial del autor y la mayoritaria del editor póstumo, tesis secundada por H. Ettinghausen [1972:223], E. Carilla [1986:47-48] y R. Moore [1989:73, nota 29].
} 
Las especulaciones críticas sobre la autoría de los epígrafes en la edición póstuma parten de las propias confesiones de González de Salas en sus «Prevenciones al lector»y en las «Ilustraciones» que acompañan a cada una de las seis musas ${ }^{41}$. En ellas se atribuye los «títulos» de los poemas e incluso ensaya una disertación teórica sobre los requisitos que cumplen o deben cumplir: síntesis temática, brevedad, valor aclaratorio y cuidado de no desvelar completamente el concepto desarrollado en el poema, para que no pierda interés:

Pero la prevención que — creo- será bien recibida de todos de los títulos míos es, que preceden a cada poesía, pues, siendo ellos muy breves, dan grande luz para la noticia del argumento que contiene cada una y, juntamente, con una cuidada destreza que yo he pretendido se haya de observar en todos los argumentos que anteceden a cualquiera escrito: que ayuden — digo — su inteligencia y la faciliten, sin que descaezcan y entibien el vigor del concepto y de la sentencia, dando de ella anteriormente noticia, pues sucede ansí $-y$, sin duda, en este defecto se peligra - cuando, ya sabidor de lo precioso y suspensivo del cuento, le escucha el oyente. Primor es grande el excusarlo y, aunque ya prevenido años ha en mi poética de Aristóteles, no le veo hasta ahora aprendido; no debe de ser muy fácil de ejecutar ${ }^{42}$.

Procede en primer lugar una somera aclaración sobre el sentido del término título, empleado por González de Salas y cuya primera acepción era en la época: «Inscripción, o rótulo exterior para el conocimiento de las cosas interiores, ocultas, o reservadas» (Autoridades). Tal definición, no asimilable exactamente a lo que hoy consideramos «título», podría aplicarse en este caso al título inicial, a la explicación siguiente, o a ambos en conjunto. Obsérvese, además, que González de Salas se refiere a continuación, como si se tratase de sinónimos, a «todos los argumentos que anteceden a cualquiera escrito»; el término argumento, definido por Autoridades como «asunto o materia de que habla algún libro», parece convenir mejor a las explicaciones que se sitúan en ocasiones bajo el título ${ }^{43}$.

${ }^{41}$ Como se sabe, la edición de la poesía de Quevedo no se completó hasta 1670, cuando su sobrino, Pedro Aldrete, publicó Las tres musas.

42 «Prevenciones al lector». González de Salas (ed.)., 1648, p. I[3. He modernizado la ortografía y la puntuación de la cita, que difiere un poco en este punto de la de la edición de Blecua, especialmente al principio: «Pero la prevención que creo será bien recibida de todos. De los títulos míos es que preceden a cada poesía» [1969:I, 94]. Aunque con otro propósito, y citando a Petronio Arbitro, el editor se refirió al asunto de las sentencias que no muestran abiertamente su sentido en su Ilustración a la poética de Aristóteles: «Coherencia, pues, han de tener, $Y$ con valentía se ha de precipitar el varonil espíritu, por la alteza del sentencioso decir, aun en los argumentos fabulosos. Pero con tal artificio que no quede eminente ni señalada la sentencia fuera del cuerpo de la oración; sino que entre sus adornos encubiertos la ennoblezca y ilumine con su esplendor» (Nueva idea de la tragedia antigua, o Ilustración última al libro singular de Poética de Aristóteles Estagirita. Sancha, Antonio (ed.). Madrid, 1770, parte primera, pp. 110-111).

${ }^{43}$ Como se dijo anteriormente, «argomento» es el término que se utiliza en el caso de las Rime de Tasso, uno de los posibles modelos de la poesía de Quevedo. 
Por otra parte, del pasaje citado del editor póstumo no es posible inferir que hubiese redactado todos los títulos: dice —en referencia al título del texto preliminar, «Prevenciones al lector»- que la prevención que será bien acogida por todos los lectores es la que atañe a sus títulos, que preceden a los poemas e iluminan su argumento. $\mathrm{Y}$ añade que ha vigilado que todos ellos cumplan unos determinados requisitos; tal observación habría podido determinar la corrección o una nueva redacción de los que no los cumplían, pero no de todos necesariamente.

Antes de mencionar las características generales de los epígrafes de la edición póstuma de la poesía de Quevedo, conviene aclarar que el análisis se referirá tanto a los títulos, por lo general breves, como a los subepígrafes, aclaraciones contextualizadoras que a veces se sitúan debajo de aquéllos y que, en algún caso, llegan a ocupar varias páginas de Parnaso.

Es ya conocida la heterogeneidad de estos paratextos, que tienen contenido diverso y, mientras son inexistentes en secciones de algunas musas, se insertan de modo sistemático y resultan especialmente prolijos en el caso de las musas II y IV.

1. Musa I, Clío ${ }^{44}$. Este primer apartado, dedicado a «elogios y memorias de príncipes y varones» (p. 5), se caracteriza por incluir siempre epígrafes que preceden a los poemas y que, siguiendo el esquema habitual de la poesía encomiástica, aclaran qué hecho o qué persona son objeto del elogio. Dada la naturaleza de esta primera musa, es muy frecuente que el título añada información circunstancial sobre algún acontecimiento de la época, como sucede, por ejemplo, en el soneto VII, «Descortesmente, y cauteloso el hado»: «Al duque de Maceda, en ocasión de no perder la silla en los grandes corcovos de su caballo, habiendo hecho buena suerte en el toro» (p. 8). Tal vez para no romper el propósito ya mencionado de la brevedad, en algún caso se añade a continuación un comentario contextualizador no integrado en el título principal; así, en el soneto XIV, «Tú, en cuyas venas caben cinco grandes», donde, tras el epígrafe «Al duque de Lerma, maese de campo general en Flandres», se aclara: «Escribió este soneto en ocasión de haber ido el duque a una interpresa y, viendo reparadas en una ribera sus tropas, se arrojó al río, y con su ejemplo todos, y ganó la plaza» (p. 13). Mención aparte requieren las prolijas disertaciones que figuran antes del soneto XXV «Faltar pudo a Escipión Roma opulenta» (p. 30) y a la canción pindárica dirigida al duque de Lerma, «De una madre nacimos» (pp. 31-43).

Las referencias a personajes y circunstancias, a veces ocultos en los poemas pero muy explícitos en el epígrafe, obligan a pensar, al menos, que el editor hubo de basarse en apuntes o indicaciones de Quevedo. No debió de

${ }^{44}$ Véase la reciente edición de esta musa, a cargo de Ignacio Arellano y Victoriano Roncero. Navarra: Eunsa, 2001. 
ser así en el caso del soneto XVI, donde el título, muy vago, sólo comenta que «es de sentencia alegórica todo este soneto», como si González de Salas no lo entendiese o careciese de datos para interpretarlo.

2. Musa II, Polimnia ${ }^{45}$. Dedicada a la poesía moral, sus epígrafes, breves por lo general, van acompañados en muchos casos de una explicación sobre las fuentes, generalmente de la antigüedad latina - Juvenal, Séneca, Persio...-, aunque también bíblicas o de la patrística, muy exactas y abundantes sobre todo al comienzo de la musa: las indicaciones sobre imitaciones se concentran, por ejemplo, en los 14 sonetos iniciales; se interrumpen o se vuelven más vagas a continuación, hasta los sonetos XXVIII y XXIX, que introducen a san Agustín y san Ambrosio; se retoman en el XXXIII, en una parte en la que proliferan las referencias estoicistas, especialmente Séneca, mencionado en los epígrafes de los sonetos XXXIII a XXXVII; posteriormente, la mención de las fuentes muestra más variedad y se hace progresivamente más escasa, aunque destaca la recuperación de Juvenal, por ejemplo entre los poemas XCVIII-C ${ }^{46}$. Como ocurría en la anterior musa, se ofrece una prolija explicación preliminar en el caso de las dos últimas composiciones, más extensas, el Sermón estoico de censura moral y la Epístola satírica y censoria (pp. 117-145).

Resulta llamativa la existencia de epígrafes que hacen referencia a una circunstancia o suceso muy concretos y no explícitos en el poema, por lo que difícilmente podrían haber sido redactados sin ayuda de Quevedo, como los sonetos LXVII, LXXVII y CVII, cuyos títulos se refieren al sonido de la campana de Velilla de Aragón, a un incendio en la plaza de Madrid o a la falsa alerta de fuego durante una fiesta de toros, respectivamente. En el primer caso, cabe recordar que el asunto de la campana suscitó en Quevedo un interés especial, a juzgar por la anotación autógrafa que existe en un ejemplar de 1633 de la obra Nueva idea de la tragedia antigua, de González de Salas, en la Sección XII, titulada «Del adorno del teatro»: «el sonido era aformado del aire que corria, no del eco, i este aire formava el sonido quando ventaba de la parte que le rezibian los meatos de la estatua, discurriendo por los guecos artificiales, dispuesto se uella, i era a la mañana porque aaquella ora siempre ai viento. i esto es cosa muii facil al Artifiçio acuerdo dela campana de Velilla en Aragón. que se muebe i suena por el lugar donde esta colocada apto a alguna repercusion de viento señalado. D. fr.co de Quevedo». (p. 177) ${ }^{47}$. Las preci-

${ }^{45} \mathrm{Ha}$ analizado con detenimiento este asunto Alfonso Rey en su edición de la poesía moral de Quevedo. Madrid: Támesis, 1999, pp. 33-35.

${ }^{46}$ Aunque no es objeto de este trabajo, la agrupación de poemas por la proximidad de sus fuentes apunta pistas sobre alguno de los criterios que pudieron manejarse en la ordenación de materiales de la musa.

${ }^{47}$ Tomo la cita del volumen con signatura (12839) de la Biblioteca de Menéndez Pelayo: ILVSTRACION AL LIBRO / DE POETICA / DE ARISTOTELES STAGIRITA. / POR / 
siones señaladas en esos poemas contrastan, una vez más, con las dudas expresadas por González de Salas en el comentario que sigue al epígrafe del soneto LXXVI: «Parece estar escrito este soneto...» (p. 94).

3. Musa III, Melpómene. Los epígrafes de esta musa, que «canta fúnebres memorias de personas insignes», se caracterizan por su brevedad y la ausencia de largos excursos; referidos mayoritariamente a un túmulo o epitafio, siguen tres pautas básicas: unos concentran en el epígrafe la mención del personaje elogiado, con su cargo, sin más aclaración, como ocurre en el soneto V, «Inscripción en el túmulo de don Pedro Girón, duque de Osuna, virrey y capitán general de las dos Sicilias» (p. 153); otros añaden, a modo de explicación complementaria, datos que permiten una mejor identificación del sujeto o circunstancias referidas por lo general a su muerte, como en el VIII, «Título funeral de Federico, hermano del marqués de Espínola», que añade debajo «Diole muerte la guarnición de su espada, teniéndola en la mano y peleando, con el golpe que en ella dio una bala de artillería» (p. 155); en tercer lugar, los que señalan cuál es el objeto personificado al que se adjudica la voz poética, la perspectiva desde la que se habla: «Habla el mármol» (VIII, p. 154), «El mármol habla» (XIV, p. 158), «Habla el mármol con Veimar, general de los suecos» y «Habla un pedazo de la nave, en que descubrió el nuevo mundo» (XXIX, p. 165). Sólo en un caso se apunta una fuente clásica, aunque imprecisa: «Es imitación de Juvenal», el soneto XI, dedicado a la figura de Aníbal. Como sucedía en las musas anteriores, una de las composiciones finales, una silva fúnebre, está precedida de un comentario sobre el origen de la forma estrófica y su aplicación en Quevedo: «Esta poesía quiso figurar nuestro poeta en canción pindárica, y con esa distribución vaga por el mundo, pero tan informe en esa estructura que pareció más acertado pensamiento, con el auxilio acostumbrado, desatarla en silva» (p. 171). El comentario, que parece atribuible a González de Salas, es uno de los que explican que se haya supuesto que el editor pudo haberse atrevido a «mejorar» los testimonios compilados tras la muerte del amigo.

En esta musa, la intervención del editor parece clara en los comentarios que siguen al epígrafe inicial, por ejemplo cuando menciona los títulos de ciertos personajes históricos; cabe pensar que las referencias concisas del epígrafe, suficientes con seguridad en el momento de los hechos relatados, habrían necesitado una aclaración mayor años más tarde, cuando González de Salas preparó los materiales para la imprenta. De esta índole sería, por ejem-

DON IVSEPE ANTONIO / GONÇALEZ DE SALAS. / NUEVA IDEA / DE LA / TRAGEDIA ANTIGUA / ILUSTRACION ULTIMA / AL LIBRO SINGULAR / DE POETICA / DE ARISTOTELES STAGIRITA / POR DON IUSEPE ANTONIO / GONÇALEZ DE SALAS. / EN MADRID. / Lo imprimio Franc. Martinez. / AÑO M DCXXXIII. / Juan de Noort / Fecit. 
plo, la explicación de que Rodrigo Calderón «murió degollado en la Plaza de Madrid» (p. 158), innecesaria, por conocida, en el momento de redacción del soneto.

4. Musa IV, Erato ${ }^{48}$. Aunque en la primera sección de Erato predominan títulos por lo general breves y sin aclaraciones complementarias, existen varios poemas en los que se inserta un comentario a continuación del epígrafe sobre el contexto de la enunciación, una costumbre antigua, las disputas filosóficas en torno a un concepto abstracto (la belleza, el amor) o una cierta tradición literaria. Tales excursos eruditos son muy significativos en las composiciones que figuran a continuación de los sonetos, tanto en estrofas foráneas (idilios, canciones y madrigales), como en composiciones insertas en la tradición castellana (redondillas y romances). Desde un punto de vista temático, los de los sonetos acostumbran a describir los sentimientos del amante — «Exageraciones de su fuego, de su llanto, de sus suspiros y de sus penas» (VIII, p. 194) — o la situación ficcional de la dama - «A Aminta, que, teniendo un clavel en la boca, por morderle, se mordió los labios y salió sangre» (XII, p. 196)—, pero también reflexionan sobre el amor o la hermosura — «Impugna la nobleza divina, de que presume el amor, con su origen y con sus efectos» (XIX, p. 199), «Quiere que la hermosura consista en el movimiento» (XXX, p. 205) - e incluso apuntan referencias mitológicas, como «Describe a Leandro fluctuante en el mar» (XX, p. 200). Los poemas en otras estrofas incluyen a veces información cotidiana, como «Celebra el cabello de una dama, que, habiéndosele mandado cortar en una enfermedad, ella no quiso» (idilio II, p. 223), pero predominan de modo notable los de carácter filosófico — «Halla en la causa de su amor todos los bienes» (romance III, p. 243) — o moral — «Advierte al tiempo de mayores hazañas, en que podrá ejercitar sus fuerzas» (romance II, p. 242)—, curiosos por referirse a poemas en arte menor y de tono menos grave, y destacan en algún caso por su brevedad conceptuosa: «Transformación imaginaria», «Alma en prisión de oro» $\mathrm{o}$ «Error acertado en condición mudable» (madrigales IV, V y VI, pp. 234-235, respectivamente).

Sobre el papel de González de Salas, evidente en casos en que dice apoyarse en comentarios del propio Quevedo sobre las circunstancias de la redacción (como en el soneto VII y su estancia en Génova), cabe señalar que existen poemas en los cuales el epígrafe nombra a una dama no mencionada después, hecho que exige suponer que hubo de ser redactado con mediación del escritor. Así sucede en la dedicatoria a una poeta llamada Antonia, en el soneto XLV, o a Flori, ausente en el texto del soneto XLVIII. También sorprende que el editor declare que el romance VII es sólo un borrador imperfecto y que no haya intervenido en él para remediarlo, como asegura haber hecho en otros casos.

\footnotetext{
${ }^{48}$ Analizó el problema de los epígrafes de Erato, y en especial los de «Canta sola a Lisi» en relación con la dispositio de este cancionero, Fernández-Mosquera [1999:341-343]. Existe edición de la primera sección [A. Rey y M. J. Alonso, 2011] y de la segunda [L. Schwartz e I. Arellano, 1998].
} 
La segunda sección de Erato, Canta sola a Lisi, la única que contiene preliminares de González de Salas (la primera carece de ellos), centrados sobre todo en las fuentes - Petrarca y su Canzoniere- y en el artificio de la elección del nombre de la amada, son en general muy breves y acostumbran a sintetizar el argumento del poema: la belleza de Lisi, su efecto en el amante o las quejas del enamorado. Aunque predominan los epígrafes simples, esto es, los constituidos sólo por un título inicial más o menos explicativo, en un caso se mencionan las fuentes — «Escribió este asunto Sannazaro: Miraris liquidum etc. Imitole Figueroa; y juntolos Herrera en el Comentario a Garcilaso» (III, p. 266)_; y en dos se aclara el contexto, cultural o científico, del poema. Destaca el del soneto $\mathrm{XV}$, próximo al de algún poema de la primera sección de la musa amorosa, en el cual, tras el título «Que amor de una vista se enciende y alimenta la llama», se ofrece la siguiente aclaración: «Esta paradoja de Amor, en que significa que el querer mirar más que una vez la superior hermosura es hacerle ofensa, se esfuerza más considerando que por esa ocasión también la antigüedad fingió al Amor ciego. Concluye luego con un concepto singular a los ojos de Lisi» (p. 270). Los títulos del madrigal y los idilios situados al final son mucho más sintéticos, como sucede en la primera sección.

5. Musa V, Terpsícore. Los epígrafes de esta musa, de carácter predominantemente burlesco, dedicada a versos «para la música de la voz y de los bailes» e integrada por letrillas, jácaras y bailes, son los más breves de Parnaso, tal vez por influencia de la tradición literaria. Cabe especular, no obstante, con la posibilidad de que la materia tratada - la sátira contra estados $u$ oficios, la crítica contra la mujer o las andanzas de jaques y valentones- y los tipos de estrofa — de la tradición castellana-, y no la ausencia de dificultad en la interpretación de los poemas (el léxico de germanías supone muchas veces un reto insalvable para el lector), hubiesen desanimado a González de Salas — si él redactó algunos de los epígrafes- a la hora de ofrecer contextos, argumentos, fuentes o tradiciones literarias.

Aunque en los preliminares de esta musa González de Salas se esfuerza por apuntar posibles precedentes clásicos, por ejemplo en el caso de los bailes, una explicación del editor previa a la primera jácara muestra sus recelos $\mathrm{y}$, al tiempo, puede justificar su aparente desdén hacia el contenido del apartado: «Dispénsese aquí la vulgaridad de este romance, por la anterioridad suya de primero (como ya se dijo en la disertación) a todos los muchos que de este genio, escritos así ingeniosamente de tantos buenos poetas, han después solicitado su imitación» (p. 341). Las letrillas (satíricas, burlescas y líricas) carecen de epígrafe, pues no puede ser considerado tal la referencia al tipo de estrofa y su número de orden; la única excepción, apenas relevante, es la indicación, a modo de «dramatis personae», «Galán y dama» (p. 335) de la segunda letrilla burlesca y «Es otro diálogo semejante» de la siguiente. Jáca- 
ras y bailes comparten el rasgo de disponer de un epígrafe breve, un poco más amplio en el caso de las primeras, con información sobre el episodio narrado o los personajes en él implicados.

Merece comentario aparte el caso de la letrilla satírica XV, único en el que figura una explicación que permite comprender quién es el sujeto satirizado: «Está escrita a sujeto particular, en ocasión de haber salido a jugar cañas».

6. Musa VI, Talía. Esta musa, la última y la más amplia de Parnaso, pues comprende casi la mitad de sus composiciones, sigue los patrones generales de la edición póstuma de 1648. Todos los poemas (sonetos, canciones, madrigales, décimas, quintillas, redondillas, romances y una sátira final en tercetos) incorporan al menos un epígrafe, por lo general muy conciso, que resume el tema. Aunque poco relevantes cuantitativamente, en proporción con la extensión de esta musa, interesa detenerse en los casos en que tras el título se incorpora un comentario sobre fuentes, contexto satírico, cuestiones textuales o circunstancias de la escritura.

Bajo el epígrafe brevísimo «A un nariz» (soneto II, p. 416), un comentario relaciona el poema con los epigramas griegos; tras un epígrafe extenso con una advertencia a los reyes, se menciona el ejemplo de dos personajes históricos mencionados en el soneto (XXVII, p. 428); un comentario etimológico sobre Judas Iscariotes sigue al título del soneto XXIX (p. 429); el título de un soneto de tono moral sobre la indignidad de quienes detentan el poder se complementa con la referencia a otra disciplina artística, la pintura, con alusión a un cuadro conocido aunque no especificado (L, p. 440).

En otro caso, bajo un epígrafe ingenioso sobre el título de vizconde, la voz del editor apunta la autoría compartida del soneto: Quevedo habría redactado los tres primeros versos, y habría pedido a González de Salas que lo siguiera, como así hizo (LXXX, p. 456); el comentario tras el epígrafe aclara la circunstancia y la razón de la composición de un soneto, en el que está implicado el duque de Lerma (p. 477).

Las cuatro canciones que siguen a los sonetos están precedidas por una explicación que, aparte de referirse a cuestiones de transmisión textual (como la presencia de alguna de ellas en una antología de principios de siglo), subrayan una vez más la supuesta manipulación de González de Salas de los poemas de su amigo: presentadas como propias de una edad juvenil, Quevedo habría querido retocarlas pero no pudo hacerlo al haberle sobrevenido la muerte, razón por la cual la labor fue realizada finalmente por el editor (pp. 457-458). Las redondillas tituladas «Celebra a una Roma, como todas lo merecen», subrayan tanto la causa de su escritura como la censura infligida al poema (no se dice por parte de quién) para hacerlo «más mesurado y decente» (p. 475).

No abundan en los romances estos subepígrafes, pero su contenido y extensión son muy variables. El más breve, «Era uno de sus apellidos sal», se 
refiere a un «perlado» al que se dedican cuatro romances (p. 513); otro ofrece la fuente folclórica para un intercambio de medicinas (p. 611); en otro, una corrida de toros con intervención del rey permite relacionar la fiesta popular con los anfiteatros y circos romanos (p. 629); a ellos se suman una explicación sobre el uso dramático del romance XCIII, escrito como loa y recitado por una comedianta (p. 632), la aclaración de que Quevedo escribió un romance cuando estaba preso en san Marcos de León (p. 636) y la justificación métrica de un romance en versos cortos, «Hero y Leandro en paños menores» (p. 639).

El romance XCIV invierte el orden habitual de los elementos -epígrafe, texto del poema y subepígrafe al final, en este caso-, y cambia también la conducta del propio editor, de ser cierta la información que proporciona, porque González de Salas advierte que deja incompleto el poema pese a su inicial voluntad de concluirlo, a modo de admonición contra quienes lo esconden o intentan apropiárselo: «En esta duda yo le suplí, por el donaire de su principio, como para divertir el ánimo [...] mudó mi propósito, dejándole ahora troncado aquí, para que piadosa ingenuidad le una a sus miembros, no mágico encanto» (p. 635).

Siguiendo un criterio que se repite en varias musas, la composición de cierre es de estrofa diferente —en este caso, escrita en tercetos y denominada «sátira»- y más extensa que las anteriores; en ella se incorpora una amplia disertación inicial con la que tal vez se pretendió atenuar algo el carácter burlesco de Talía y un cierre más próximo al discurso moral: tras las referencias a Juvenal, Lupercio Leonardo de Argensola y Petronio, concluye que «Pareció añadirse en el fin de esta musa, por lo que el estilo en ella jocoso tanto prevalece, pues, aunque por la parte de censura moral de algunos vicios convenía a la musa II, como ella castigó allá, tan triste y severa, este sabor burlesco, sin duda se sintiera entonces desazonado y importuno» (p. 652).

Como en las musas anteriores, existen abundantes títulos y comentarios complementarios del epígrafe inicial que González de Salas no podría haber redactado sin intervención de Quevedo. Así sucede cuando se aclaran las circunstancias biográficas del escritor que le llevaron a componer el poema, por ejemplo una consulta que hicieron a Quevedo en el soneto LXXX, el enfado de un caballero ofendido por una roma en unas redondillas (p. 475), el encuentro de Quevedo con el duque de Lerma (p. 477), o la escritura de los textos en la prisión de San Marcos de León, en los romances LXXXVIII y $\mathrm{XCV}$. A ello se añaden los casos en que el título inicial ofrece información difícilmente deducible a partir del contenido del poema, como las referencias a la competencia entre la Casa de Campo y el Retiro, en el soneto XXXVII, o la alusión al origen francés de un tendero, en el soneto LXXII.

El análisis precedente muestra que epígrafes y subepígrafes constituyen parte fundamental del diseño editorial de la primera edición de la poesía com- 
pleta de Quevedo: los primeros se incluyen sin excepción en las seis musas de Parnaso, aunque en la quinta, Terpsícore, faltan en la sección de las letrillas. Los más breves son los de los de las musas quinta, primera y tercera, así como los de Talía, aunque con excepciones significativas ya señaladas; los más ricos en información (por cantidad de datos y por variedad de materias tratadas) son los de Polimnia y, sobre todo, los de Erato, especialmente en su primera sección, un dato que parece lógico, a juzgar por el mayor prestigio que las materias moral y amorosa tenían en la tradición literaria, frente a la burlesca por ejemplo. Es muy frecuente que los epígrafes vayan seguidos de subepígrafes, de extensión variable y que puede exceder de una página, que sirven para una mejor contextualización del tema del poema. Por otra parte, el contenido de epígrafes y subepígrafes es de naturaleza diversa: desde el que resume el tema de la composición o aclara sus fuentes hasta el que ofrece detalles sobre la circunstancia concreta que sirvió de inspiración, pasando por las reflexiones literarias o ideológicas, por los avatares textuales o por la autoría compartida — de Quevedo y González de Salas- en ciertos casos. Finalmente, en todas las musas existen casos en que la información explícita en el epígrafe o en el comentario siguiente hacen imprescindible la intervención de Quevedo.

\section{LAS TRES MUSAS}

Conocidas son las palabras de Pedro Aldrete, sobrino de Quevedo y editor de la segunda parte de su poesía (Las tres musas, 1670), en el prológo «Al lector», donde afirma que publica los poemas tal y como los dejó el escritor:

«he procurado se junten en este libro las que he podido conseguir, y que todas las poesías que comprehende se impriman en la mesma conformidad que las dejó [Quevedo], sin añadir ni quitar cosa alguna. Bien veo que les faltan muchos asuntos, y las que los tienen están defectuosos y no tienen el lugar que les toca ${ }^{49}$.

Cabe interpretar el término asuntos — «La materia o tema de la oración, poesía, u discurso sobre que principalmente se trata» (Autoridades) - como equivalente de epígrafes según la acepción moderna, pero quizá no tanto como sinónimo de títulos, si entendemos esta palabra de acuerdo con su sentido habitual en la época, el que presumiblemente usó González de Salas.

Aunque existe la idea de que muchos de los poemas incluidos en las musas Euterpe, Calíope y Urania carecen de estas notas iniciales, hecho que reforzaría la hipótesis de que los epígrafes de El Parnaso son obra del editor y no de Quevedo, lo cierto es que son mayoría los que sí lo tienen, en especial numerosos sonetos amorosos, todas las silvas y los poemas religiosos, en alp. 142 .

${ }^{49}$ Sigo la primera edición, de 1670, en Madrid: Imprenta Real, p. [I[5]; véase Blecua, I, 
gún caso de extensión equiparable a los más largos de El Parnaso. No hay, eso sí, explicaciones complementarias de los epígrafes salvo en dos únicos casos explicados más adelante. ¿Habría Quevedo redactado los epígrafes que se conservan - lo que no obsta para que González de Salas los hubiese rehecho o compuesto en su forma definitiva-, y por eso se encuentran en las ediciones de 1648 y 1670 ? ¿Habría redactado por completo González de Salas sólo los excursos, a los que habría denominado «títulos», y por eso figuran únicamente en El Parnaso y no en Las tres musas?

Como sucede en la edición de 1648, la de 1670 incorpora epígrafes en cada una de las tres últimas musas, pero existen diferencias reseñables.

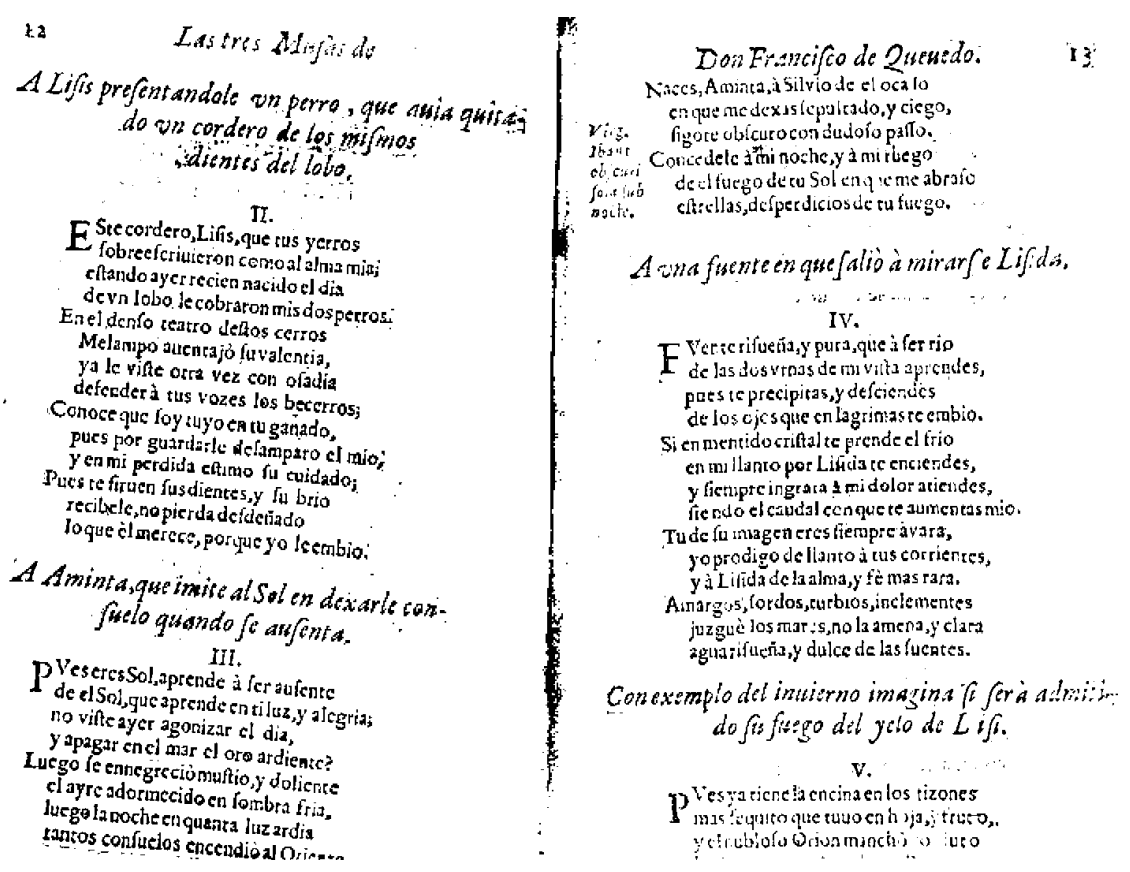

LÁmiNA 4. Edición de Las tres musas (1670), a cargo de Aldrete.

7. Musa VII, Euterpe. Los siete poemas iniciales que inauguran este apartado y la edición de Aldrete, de trasfondo moral, tienen breves epígrafes referidos al tema o al sujeto satirizado, a veces con tono exhortativo: «A la brevedad de la vida» (p. 1), «Muestra lo que es una mujer despreciada» (p. 2), «Pinta la vanidad y locura mundana» (p. 3), «Un hombre desengañado» (p. 9). 
Aunque bajo el rótulo de «sonetos pastoriles», los 23 poemas editados a continuación son prioritariamente de tema amoroso y tocan asuntos muy próximos a los de la musa Erato de Parnaso, además de contener referencias a Lisis, Lísidas, Amintas, etc; pero la relación no es sólo argumental, sino que atañe también a los títulos, más amplios que los anteriores ${ }^{50}$ : «A Lísida, pidiéndole unas flores que tenía en la mano, y persuadiéndola imite a una fuente» (I, p. 11); «Con ejemplo del invierno imagina si será admitido su fuego del yelo de Lisi» (V, p. 13); «Significa el mal que entra a la alma por los ojos con la fábula de Acteón» (XI, p. 17); «Dice que, como el Nilo guarda su origen, encubre también el de su amor la causa» (XII, p. 18); «A Lisi, que en su cabello rubio tenía sembrados claveles carmesíes, y por el cuello» (XVI, p. 21$)^{51}$.

Menor homogeneidad existe en el resto de la musa, que acoge a continuación «Poesías amorosas», aunque algunas sean de materia burlesca, y entre las que figuran 38 sonetos, de los cuales sólo 4 contienen epígrafes, especialmente breves: «En lo penoso de un amante ausente» (p. 26) ${ }^{52}$ «Culpa lo cruel de su dama» (p. 27); «Quéjase de lo esquivo de su dama» (p. 27); y «A un retrato de una dama» (p. 36). Hay, además, 1 poema en octavas, con el epígrafe «Que todo tiene fin sino es mi pena» (p. 45); 8 canciones, 2 de las cuales tienen los títulos «Mostrando su pasión amorosa» (p. 46) y «Muestra el poder del amor» (p. 47); 1 poema en décimas sin epígrafe; 3 en redondillas, titulados «Muestra lo enamorado en lo ausente» (p. 61), «Muestra lo enamorado» (p. 62) $\mathrm{y}$ «Redondillas en lo penoso de estar enamorado» (p. 62); y 18 romances, mayoritariamente clasificados sólo como «amorosos», «satíricos» o «burlescos», pero que en algún caso incorporan epígrafes que apuntan el tema: «Quejas de un amante» (p. 63), «Al salir los reyes en tiempo de Felipe tercero» (p. 65), «Vejamen a una dama» (p. 67), «Sátira a los coches» (p. 69), «A la sarna» (p. 70), «Al pasarse la Corte a Valladolid» (p. 73). La musa se completa con 1 poema en endechas sin título y 1 poema en tercetos titulado «Sátira a una dama» (p. 86), antes de los 3 entremeses que cierran el conjunto.

${ }^{50}$ En la lámina 4, que contiene parcial o totalmente sonetos «pastoriles» de la musa VII, Euterpe, se observa la proximidad de sus epígrafes respecto a los amorosos de Erato; incluso existe alguna nota filológica, como la que figura en el margen izquierdo de la página 13: «Virg. Ibant obscuri sola sub nocte».

${ }^{51}$ Considerando Canta sola a Lisi, la segunda sección de Erato, como un peculiar cancionero petrarquista, llama la atención que existan varios poemas dedicados a Lisi en la musa VII, Euterpe, que no fueron incluidos en aquél como correspondería.

${ }^{52}$ Este poema, «Embravecí llorando la corriente», se recoge aquí con una versión notablemente variante respecto a la de la musa IV, Erato, bajo el título «Llanto, presunción, culto y tristeza amorosa», cuyo primer verso es «Esforzaron mis ojos la corriente» [317]. Es uno de los 14 casos de poemas repetidos o duplicados por Aldrete, según la edición de Pedraza [1999] de Las tres musas. 
8. Musa VIII, Calíope. Conocido por contener parcialmente el corpus quevediano de silvas morales ${ }^{53}$, este apartado comienza con unas quintillas tituladas «Juicio moral de los cometas» y cinco letrillas satíricas o burlescas, de las cuales sólo una incluye epígrafe, «Letra satírica a la fortuna» (p. 130), un dato concordante con el criterio establecido en Parnaso, donde casi todas las letrillas, agrupadas en Terpsícore, carecían de títulos. Los epígrafes, que preceden a cada uno de los 32 poemas incluidos hasta el final de la musa, se pueden clasificar en tres tipos atendiendo a su extensión, que parece relacionada con el asunto. Un primer grupo, configurado por poemas cuyo título, lacónico, es sólo un sintagma sustantivo, tiene un marcado carácter moral dirigido contra algún vicio o motivo de la tradición literaria: «La soberbia» (1, p. 132), «El sueño» (2, p. 134), «El escarmiento» (18, p. 176), «El pincel» (25, p. 196) y «El arroyo» (p. 215). El segundo contendría epígrafes de tamaño intermedio, más próximos a la extensión media y también predominantemente - aunque no sólo- morales, entre los cuales se incluyen algunos de la serie dedicada a los relojes: «La mina de oro contra la avaricia» (3, p. 137), «Roma antigua y moderna» (4, p. 139; repetida como «A Roma antigua y moderna» en 13, p. 163), «Exhortación a una nave nueva al entrar en el agua» (5, p. 145), «Farmaceutria o medicamentos enamorados» (6, p. 147), «El reloj de arena» (7, p. 152), «Reloj de campanilla» $(8$, p. 153$)$, «El reloj de sol» $(10$, p. 156) y «Execración contra el inventor de la artillería» $\left(11\right.$, p. 157), por ejemplo ${ }^{54}$.

Los más extensos, como sucedía en la musa IV de Parnaso, pueden encuadrarse en el tema amoroso, aunque hay también algún poema moral, uno de elogio y uno satírico; en estos casos, la mayor extensión parece inducida por la necesidad de apuntar ciertas circunstancias necesarias para la comprensión del poema: «Al polvo de un amante, que en un reloj de vidrio servía de arena a Floris, que le abrazó» $(9$, p. 155), «A los huesos de un rey que se hallaron en un sepulcro, ignorándose, y se conoció por los pedazos de una corona» (12, p. 160); «Al jabalí, a quien dio muerte con una bala la serenísima infanta doña María, después reina de Hungría y emperatriz de Alemania» (21, p. 183); y «Describe una recreación y Casa de Campo de un valido de los señores Reyes Católicos, don Fernando y doña Isabel» (22, p. 187), entre otros ${ }^{55}$.

${ }^{53}$ Sobre este asunto y la ordenación de las silvas, véase el estudio de Rey [2006].

${ }^{54}$ Añádanse los siguientes casos: «A un ramo que se desgajó con el peso de su fruta» (14, p. 168), «Amante que vuelve a ver la fuente de donde se ausentó» (15, p. 169), «Himno a las estrellas» (16, p. 172), «El yelmo de Segura de la Sierra, monte muy alto al Austro» (17, p. 174), «Muere infeliz y ausente Ioylio» (19, p. 180), «Ansia de amante porfiado» (20, p. 181), «Al tiempo, enamorada invocando su valentía contra el rigor de su mal» (24, p. 193), «En alabanza de la pintura de algunos pintores españoles» (26, p. 201), «A don Jerónimo de Mata, en el libro de las tristezas de Amarilis» (27, p. 205), «Alaba la calamidad» $(30$, p. 213$)$ y el romance «El Cid acredita su valor contra la invidia de cobardes, en lenguaje antiguo» (p. 215).

${ }^{55}$ En este grupo entrarían, asimismo, «Cabellos de Aminta que mandó un médico que se los cortasen en un tabardillo; ella no le obedeció. Es agradecimiento a Aminta y reprehen- 
Existen en esta musa, y en el conjunto de Las tres musas, dos casos únicos de inclusión de epígrafe y subepígrafe, práctica editorial ya referida para el caso de El Parnaso y muy característica de la primera sección de Erato; tal vez no por causalidad son silvas amorosas, de tono burlesco la primera y de carácter encomiástico la otra: el título inicial de la primera es «Quéjase del rigor de una hermosura, que no le miró por mirar a un hombre muerto que tenían en público para que le reconociesen» y, tras él, se sitúa una información adicional sobre su estilo, «Está escrita con estilo fácil y sencillo, a instancia de un gran señor, a quien había sucedido escribió esta silva, aunque le dejó no como aquí se lee» (23, p. 191); el epígrafe es en la segunda «A don Jerónimo de Mata en el libro de las tristezas de Amarilis», y el subepígrafe, situado bajo la indicación «Strophe», «Sigue la disposición de las Odas de Píndaro» (27, p. 205). Blecua [1969:I, pp. 581 y 483] apuntó la posibilidad de que tales subepígrafes hubiesen sido redactados por González de Salas y cedidos a Aldrete, pero nada impide la posible autoría quevediana.

9. Musa IX, Urania. De carácter religioso, aunque con algunas incoherencias (un poema épico burlesco extenso, entre otras), contiene en su parte inicial 43 sonetos, todos con epígrafe indicativo del tema y al cual se añade muchas veces una aclaración de las fuentes sagradas; este hecho explica su amplitud, acentuada en ocasiones por la reproducción del texto latino que sirve como base: «Reprehende la insolencia de los que se atreven a preguntar a Dios las causas por que obra y deja de obrar con estas palabras de S. Pablo: Numquid [...] contumeliam» (X, p. 222); «Por los reyes buenos, de quien murmuran malos vasallos, muestra cuán antiguo es tapar a los reyes lo ojos, con el texto de san Marcos, cap. 14. Et coeperunt [...] prophetiza» (XV, p. 225); «A san Lorenzo, glorioso mártir español, que murió asado en parrillas, considerando las palabras que dijo al tirano, convidándole a comer la parte de su cuerpo que ya estaba asada, y sobre las palabras de san Pedro Crisólogo, sermón CXXXV. Plus ardebat, quam vrebat»(XXXIV, p. 236).

La fórmula antedicha es la mayoritaria en los sonetos, pero en algún caso los epígrafes se extienden por incluir aclaraciones sobre el contexto histórico o un episodio bíblico: «A un hermosísimo pedazo de cristal de que el duque de Lerma, con gran susto, hizo una custodia que para el santísimo sacramento dio al convento de san Pablo de Valladolid; dice poéticamente las opiniones que hay cerca de la naturaleza del cristal» (XII, p. 223). Más próximos a los epígrafes habituales son los de sonetos que no pretenden recrear un pasaje sagrado ni necesitan explicaciones contextualizadoras para su comprensión: «A Jesucristo nuestro señor, expirando en la cruz» (I, p. 217); «Pide a Dios

sión al doctor» (28, p. 207); y «Abomina el abuso de la gala en los diciplinantes, con que alguno ha quedado ya persuadido y se azota retirado; y se podría esperar el mesmo efecto en muchos que lean ésta» (29, p. 209). 
le dé lo que le conviene, con sospecha de sus propios deseos» (XVII, p. 226); «Reconocimiento propio y ruego piadoso antes de comulgar» (XXVI, p. 231); o «A una iglesia muy pobre y oscura con una lámpara de barro» (XXXII, p. 235).

Los cinco ovillejos que siguen contienen títulos breves o muy breves: «A san Pedro cuando negó a Cristo señor nuestro» (p. 242), «A Judas Escariote cuando vendió a Cristo señor nuestro» (p. 243), «A Caín cuando mató a su hermano» (p. 243), «A la soberbia» (p. 244) y «A un pecador» (p. 244). El cancionero Lágrimas de un penitente está configurado por 17 salmos sin título, en consonancia con el corpus del que deriva, Heráclito cristiano (1613), donde los salmos también aparecen numerados y sin epígrafe ${ }^{56}$. La redondilla única tiene el epígrafe «Recuerdo y consuelo en lo mísero de esta vida» (p. 254), y los 3 romances siguen la fórmula de los epígrafes breves: «Lamentándose Job: Pereat dies, in qua natus sum» (p. 255), «A don Álvaro de Luna» (p. 257), «A nuestra Señora en su nacimiento» (p. 258). La musa novena se cierra con composiciones largas con título de obra independiente, de ahí que no incluyan epígrafes: Padre nuestro, Poema heroico a Cristo resucitado, los fragmentos de Cantar de lo Cantares y el Poema heroico de las necedades y locuras de Orlando el enamorado. En medio de los dos últimos se insertan poesías fúnebres: 3 sonetos con títulos muy breves, referidos a su condición de epitafio dirigido a una señora en dos casos y al «pésame a su marido» (p. 304); y una canción sin epígrafe.

De la explicación previa se infieren los siguientes resultados: la musa Euterpe, integrada por 101 poemas, carece de epígrafes en la mitad de ellos: 33 sonetos, 6 canciones, 1 poema en décimas, 11 romances, 1 poema en endechas; la musa Calíope, que contiene 39 poemas, únicamente edita sin títulos 4 letrillas; la musa Urania, conformada por 77 poemas (algunos de gran extensión), sólo carece de epígrafes en los 17 salmos de Lágrimas de un penitente y una canción fúnebre. Además, existe una correspondencia muy acusada entre los epígrafes de las ediciones de 1648 y 1670, especialmente patente en poemas del mismo tipo: textos morales y amorosos de Las tres musas se imprimen con títulos de factura similar a los de Erato y Polimnia, en Parnaso, con la única excepción ya comentada de los sonetos amorosos sin epígrafe de Euterpe; como en Parnaso, las letrillas carecen de más especificación que su tipo (satíricas o burlescas). Finalmente, en Las tres musas el epígrafe es único, sin las aclaraciones que siguen al título en algunos poemas de Parnaso, salvo en dos casos.

\footnotetext{
${ }^{56}$ Tomo este dato sobre el cancionero de una copia del testimonio conocido como «manuscrito Asensio», integrado por 26 salmos y hoy en paradero desconocido; también carecen de título los 25 poemas de Heráclito cristiano copiados en el Cancionero de 1628, custodiado en la Biblioteca Universitaria de Zaragoza, con signatura M-247, ff. 1-10v.
} 


\section{EVOLUCIÓN DE LOS EPÍGRAFES}

La comparación de los epígrafes y el análisis de su evolución permite comprobar que los de la edición de González de Salas acostumbran a diferir bastante de los de difusión más temprana, con la excepción significativa de los autógrafos conservados en el manuscrito de Nápoles, cuyos epígrafes son casi idénticos a los de Parnaso. En el resto de los casos pueden apreciarse diversas posibilidades de una hipotética intervención del autor o del editor. Aunque algunas parecen corresponderse con los objetivos por éste enunciados en el prólogo -indicación del tema, brevedad y preservación del interés, sin desvelarlo todo-, ello no excluiría la iniciativa del propio Quevedo. Se sintetizan a continuación las que parecen tendencias más significativas:

- Cambios para conseguir una mayor adecuación temática a la musa. Sucede, por ejemplo en Melpómene, de carácter funeral; o en Erato y el cancionero «Canta sola a Lisi», amoroso: «Mi madre tuve en ásperas montañas», «Sepulcro de Jasón el Argonauta» $(P, 157)$; «A la primera nave del mundo» (Flores y «Évora») ${ }^{57}$. «Salamandra frondosa y bien poblada», «Ardor disimulado de amante» $(P, 195)$; «Al Vesubio, que interpoladamente es jardín y volcán...» (Quiñones, El monte Vesubio, 1632). «Descansa en sueño, ¡oh tierno y dulce pecho», «A una niña muy hermosa, que dormía en las faldas de Lisi» (P, 284); «Descansa del calor del tierno pecho», «El mismo, a una niña que dormía en las faldas de una dama» (C. Antequerano). En este caso, la dama indeterminada se convierte en Lisi, dentro ya del cancionero de inspiración petrarquista.

- Construcción de una sentencia de mayor y más general alcance moral, a partir del ejemplo concreto: «De los misterios a los brindis llevas», «Espántase de la advertencia quien tiene olvidada la culpa» $(P, 113)$; «Al rey Baltasar, cuando profanó en el convite los vasos sagrados del templo y vio una mano, comiendo, que escribía en la pared estas palabras: Mane, Tezel, Phares» (Tres musas, p. 227). «Llueve, oh Dios, sobre mi persecuciones», «Que el espíritu sin culpa no tema los trabajos enviados del cielo» $(P, 77)$; «A estas animosas palabras que decía Epicteto: "Plue, Jupiter, super me calamitates"» (Epicteto y Phocilides, 1635).

- Contextualización enfatizadora del papel del editor: «Retirado en la paz de estos desiertos». «Algunos años antes de su prisión última, me envió este excelente soneto desde La Torre» $(P, 115)$; «Comercio de difuntos contrapuntos» (autógrafo, British Museum); también epígrafe en ms. 4312: «Habiendo enviudado y retirádose de la comunicación escribió este soneto».

${ }^{57}$ En cada ejemplo las referencias siguen este orden: primer verso del poema, epígrafe en Parnaso o Tres Musas y epígrafe en colecciones tempranas. 
- Agudeza conceptuosa. «Óyeme riguroso», «Celebra la pureza de una dama vinosa» $(P, 462)$; «A una dama hermosa y borracha» (Cancionero 1628); «A una dama borracha» (C. antequerano).

- Propósito de síntesis. «¡Oh corvas almas, oh facinorosos», «Sermón estoico de censura moral» $(P, 127)$; «Sermón estoico a las desórdenes de los apetitos» (Cancionero antequerano). «Ciego eres, Amor, y no», «Declama contra el Amor» $(P, 530)$; «Al Amor, diciéndole por proverbio su origen $\mathrm{y}$ calidades de sus progenitores» (ms. 3940).

- Aprovechamiento de la información del epígrafe más antiguo para el subepígrafe. Sucede, por ejemplo, en el soneto XI de Melpómene, en el XLVIII de Polimnia y en el XI de Erato. En este último, «Salamandra frondosa y bien poblada», el título de Parnaso es «Ardor disimulado de amante» $(P, 195)$, mientras que en la versión publicada en 1632 figuraba «Al Vesubio, que interpoladamente es jardín y volcán...» (Quiñones, El monte Vesubio). La aclaración que sigue al epígrafe de la edición póstuma parece recrear el de publicación más temprana: «El monte Vesubio, hoy llamado la montaña de Soma, arde en la cima, vestido en contorno de jardines» (p. 195).

- Eliminación de referencias religiosas. «Cubriendo con cuatro cuernos», «En la simulada figura de unas prendas ridículas, burla de la vana estimación que hacen los amantes de semejantes amores» $(P, 557)$; «A un sacristán, haciendo alarde de los favores de su dama y dejándolos en el campo» (ms. 3940); «A un sacristán, amante ridículo» (Maravillas del Parnaso).

- Mención de una figura política relevante. «En el bruto, que fue bajel viviente», «Al toro a quien con bala dio muerte el rey nuestro señor» $(P, 11)$; «Epitafio al león vivo en el toro muerto» (Anfiteatro de Pellicer, 1631).

- Cambio de orden inducido por circunstancias políticas diferentes. «No he de callar por más que con el dedo». La mención inicial al Conde-Duque de Olivares, en Discurso de los tufos, de 1629, y en el ms. «Harvard», se pasa al final en el epígrafe de Parnaso: «Epístola satírica y censoria contra las costumbres presentes de los castellanos, escrita a don Gaspar de Guzmán, conde de Olivares en su valimiento». Piénsese que este personaje se convirtió en valido de Felipe IV en 1621; caído en desgracia tras diversas iniciativas de reforma muy contestadas, fue desterrado en 1643, razón por la cual resulta lógico que en 1648 ya no encabece el título del poema.

- Sustitución de una referencia impersonal por otra más subjetiva que parece aludir a Quevedo: «Hace últimamente su testamento» $(P, 297)$, por «Silva 24. Testamento amoroso» (Nápoles); «Lamenta su muerte y hace epitafio a su sepulcro» $(P, 296)$, por «Amante que muere. Silva 22» (Nápoles).

La edición de Pedro Aldrete destaca, por el contrario, por la semejanza de sus epígrafes con los recogidos en ediciones o manuscritos tempranos de los poemas. Tal coincidencia generalizada, que admite algunas discrepancias en el caso de las silvas autógrafas del manuscrito de Nápoles, se aprecia en los 
siguientes ejemplos: «Dónde vas, ignorante navecilla», «Silva quinta. Exhortación a una nave nueva al entrar en el agua» (TM, 145); «Silva. Exhortando a una nave nueva al entrar en el agua» («Évora»); «A una nave» (Flores 1611). «Qué tienes que contar, reloj molesto», «El reloj de arena» (TM, 152); «Reloj de arena» (Flores 1611); «Madrigal de don Francisco de Quevedo al reloj de arena» (Cancionero antequerano). «En cárcel de metal, ;oh atrevimiento», «Silva II. Execración contra el inventor de la artillería» $(T M, 157)$; «Silva 18. $\mathrm{Al}$ inventor de la artillería» («Nápoles»); «Silva XI. Al inventor de la artillería» («Évora»). «¿Con qué culpa tan grave», «El sueño» $(T M, 134)$; «Al sueño» (Flores 1611, «Nápoles», «Évora», Cancionero antequerano, con diferencias en el rótulo de silva o canción).

Los ejemplos señalados, sólo una breve muestra de los existentes, reflejan que los epígrafes de Parnaso se parecen menos que los de Tres musas a los de copias o publicaciones tempranas de los poemas, y parecen haber experimentado una reelaboración en un doble sentido: en muchos casos se acortan y a veces (especialmente en poemas morales y amorosos) cambian su contenido y buscan un tono más sentencioso, de aplicación general y no tan atenida al caso concreto. La tendencia señalada se atenúa en los poemas autógrafos de Nápoles, cuyos epígrafes apenas se transforman en Parnaso. Por otra parte, cabe señalar que las alusiones a la relación de González de Salas con Quevedo o su poesía sólo están en epígrafes de Parnaso; que los de Tres musas acostumbran a reflejar la misma información básica, con variaciones sólo de forma y no de fondo, de las versiones tempranas; y que los epígrafes se insertan incluso en composiciones que circularon en antologías tempranas pero no fueron incluidas en las ediciones póstumas ${ }^{58}$.

\section{CONCLUSIONES}

El análisis precedente permite apuntar las siguientes conclusiones sobre las razones, las circunstancias y el proceso de redacción de los epígrafes de las ediciones póstumas de la poesía de Quevedo.

1. Quevedo, buen conocedor de la literatura grecolatina y de la tradición italiana, habría podido concebir sus poemas imitando no sólo temas, tópicos, recursos y estrofas, sino también un recurso gráfico y de contenido que, presente en textos de la poesía erótica griega, las silvas de Estacio o los epigramas de Marcial, parece haberse convertido casi en norma en la poesía amorosa y burlesca italiana de los siglos XVI y XVII: la anteposición de breves títulos que mencionan el destinatario, la circunstancia, el tema o algún indicio de la agudeza propuesta, como sucede, por ejemplo, en las Rime de Tas-

\footnotetext{
${ }^{58}$ Este apartado es un resumen de las conclusiones obtenidas del estudio de los datos comparativos incluidos en el cuadro del apéndice final.
} 
so y Marino. Añádase a ello el ejemplo de los poemas morales de Luis de León, los sonetos de Góngora, las composiciones burlescas de Lope o los romances de germanías. No parece necesario, por tanto, recurrir a la figura de González de Salas para explicar la presencia de los epígrafes, sobre todo si tenemos en cuenta que algunos de los poemas editados por Aldrete tal vez llegaron a sus manos directamente desde las de su tío, y que la mayoría disponen de estos títulos.

2. Aunque faltan datos textuales, el cotejo de los epígrafes de las ediciones de 1648 y 1670 y los que se incluyen en poemas de publicación o difusión manuscrita temprana permite hacer dos afirmaciones básicas: a) abundan los poemas con título en colecciones datadas con total seguridad, como Flores de poetas ilustres (1605), Segunda parte de Flores (1611) o el Cancionero de 1628; b) en algún caso, incluso, poemas autógrafos (un soneto moral y la colección de silvas del manuscrito de Nápoles) contienen epígrafes debidos sin duda a Quevedo, cuya redacción y sentido fueron mayoritariamente respetados en las ediciones de 1648 y 1670. La frecuencia con que aparecen epígrafes en poemas de Quevedo difundidos en las primeras décadas del siglo XVII — cuando González de Salas aún estaba lejos de iniciar su labor como editor e hipotético redactor de los títulos-, así como su presencia en textos autógrafos, invitan a suponer que pudo haberlos escrito o sugerido de forma sistemática; su esbozo habría servido al menos de base para los que finalmente se incluyeron en las ediciones póstumas de su poesía.

3. Cuando González de Salas y Aldrete se refirieron a los encabezamientos de los poemas de Quevedo lo hicieron con términos no coincidentes, por lo que podrían no referirse exactamente a lo mismo. De hecho, aunque el primero se atribuyó la redacción de todos los «títulos», lo cierto es que la historia textual de los poemas demuestra que muchos de ellos los tenían antes de su intervención. Cabe pensar, por tanto, que el término se referiría, de modo impreciso, tanto al epígrafe inicial como al subepígrafe, habida cuenta de que alude a los títulos también con el término «argumentos»: el primero no siempre habría sido redactado por González de Salas, sino sólo retocado por él en algún caso; el segundo tal vez sí, aunque a partir de indicaciones o notas del propio Quevedo, dado que en algunos poemas apuntan circunstancias imposibles de conocer de no haber sido así. Aldrete menciona que faltan muchos de los «asuntos» ${ }^{59}$, y algunos están trastocados de lugar; tal información, que se referiría en exclusiva a los títulos y no a los subepígrafes — por-

\footnotetext{
${ }^{59}$ Una muestra más de la fluctuación de acepciones en la época es la aclaración de Pedro de Espinosa de que en uno de los poemas de Quevedo el «sujeto» es el mar; por el contexto, este término puede tener el sentido de «la materia, asunto o tema de lo que se habla o escribe» (Autoridades), intercambiable, por tanto, con otros como «título» o «asunto».
} 
que Las tres musas carece de ellas salvo en dos casos- parece creíble, a juzgar por la existencia de grupos de poemas que carecen de toda indicación inicial sobre su tema.

4. Tanto en El Parnaso como en Las tres musas es preciso subrayar la presencia mayoritaria de títulos o epígrafes, que sólo no se incorporan en subgéneros que carecían de ellos en la tradición literaria (las letrillas, por ejemplo) o en grupos de composiciones que, en los orígenes de su transmisión textual, configuraron un corpus con el número del poema como única indicación previa (el caso de los salmos de Heráclito cristiano y Lágrimas de un penitente). No es fácil explicar, por el contrario, el caso de los sonetos de Euterpe sin epígrafe, aunque integrarían ese grupo de los que llegaron a Aldrete carentes de «asunto», tal como éste menciona en sus páginas preliminares.

5. Si se compara la evolución de los títulos desde su formulación más temprana hasta la definitiva de la edición póstuma ${ }^{60}$, se observan tendencias significativas por contrapuestas: los epígrafes incluidos por González de Salas presentan cambios sustanciales en muchos casos (no así respecto a los autógrafos), que por lo general apartan un tanto el texto de una circunstancia concreta, a veces prosaica, para darle un nuevo tono más general y filosófico; los de Aldrete apenas alteran la información de las versiones primitivas y sólo suponen cambios sintácticos o léxicos sin relevancia para la interpretación del poema. Por otra parte, en los casos de poemas incluidos en Parnaso y en Tres musas, la versión del epígrafe del primero suele ser más sintética que la del otro.

Los hechos enumerados, constatables en los ejemplos aducidos, admiten la siguiente hipótesis: Quevedo habría redactado muchos de sus poemas con epígrafes, que podría haber modificado en el caso de composiciones con versiones variantes, y que en ocasiones pudieron ser manipulados por González de Salas debido a razones múltiples (acentuación de la moralidad de los textos, eliminación de referencias que, por circunstanciales, tendrían poco interés varias décadas más tarde, atribución de un mayor grado de amistad o intervención en los textos de su amigo, etc.); Aldrete, por el contrario, habría reproducido los textos como los recibió — así lo afirma en el prólogo-, esto es, en algún caso con epígrafes tal vez originales de su autor.

\footnotetext{
${ }^{60}$ Sobre la presumible posterioridad de las versiones incluidas en Parnaso y Las tres musas, véase Rey [1999 y 2006].
} 


\section{APÉNDICE. CUADRO COMPARATIVO DE EPÍGRAFES ${ }^{61}$}

\begin{tabular}{|c|c|c|c|c|}
\hline $\begin{array}{c}\text { MUSASY } \\
\text { PRIMER VERSO }\end{array}$ & PARNASO (1648) & TRESMUSAS (1670) & $\begin{array}{l}\text { TESTIMONIOS } \\
\text { TEMPRANOS }\end{array}$ & $\begin{array}{l}\text { TESTIMONIOS } \\
\text { TEMPRANOS }\end{array}$ \\
\hline $\begin{array}{l}\text { CLíO } \\
\text { «Tú sólo en los errores } \\
\text { acertado» }\end{array}$ & $\begin{array}{l}\text { «Celebra el esfuerzo de } \\
\text { Quinto Mucio, } \\
\text { después llamado } \\
\text { Scevola» }(P, 9)\end{array}$ & & $\begin{array}{l}\text { «Túmulo a Scévola» } \\
\text { (Cancionern antequerano, } \\
\text { 1627-1628) }\end{array}$ & \\
\hline $\begin{array}{l}\text { «En el bruto, que fue } \\
\text { bajel viviente» }\end{array}$ & $\begin{array}{l}\text { «Al toro a quien con } \\
\text { bala dio muerte el rey } \\
\text { nuestro señon» }(P, 11)\end{array}$ & & $\begin{array}{l}\text { «Epitafio al león vivo } \\
\text { en el toro muerto» } \\
\text { (Anfiteatro de Pellicer, } \\
\text { 1631) }\end{array}$ & \\
\hline $\begin{array}{l}\text { POLIMNIA } \\
\text { «Esta miseria, gran } \\
\text { señor, honrosa»; }\end{array}$ & $\begin{array}{l}\text { «Séneca vuelve a } \\
\text { Nerón la riqueza que } \\
\text { le había dado» }(P, 50)\end{array}$ & & $\begin{array}{l}\text { «Otro del mismo. } \\
\text { Volviendo Séneca a } \\
\text { Nerón las riquezas que } \\
\text { le había dado» (ms. } \\
\text { «Évora», sigło XVII) }\end{array}$ & \\
\hline $\begin{array}{l}\text { «lueve, oh Dios, } \\
\text { sobre mi } \\
\text { persecuciones» }\end{array}$ & $\begin{array}{l}\text { "Que el espíritu sin } \\
\text { culpa no tema los } \\
\text { trabajos enviados del } \\
\text { cielo» }(P, 77)\end{array}$ & & $\begin{array}{l}\text { «A estas animosas } \\
\text { palabras que decía } \\
\text { Epicteto: "Plue, } \\
\text { Jupiter, super me } \\
\text { calamitates"» (Epicteto y } \\
\text { Phocilides, 1635) }\end{array}$ & \\
\hline $\begin{array}{l}\text { «a voluntad de Dios } \\
\text { por grillos tienes» }\end{array}$ & $\begin{array}{l}\text { "Comprehende la } \\
\text { obediencia del mar y la } \\
\text { inobediencia del } \\
\text { codicioso en sus } \\
\text { afectos» }(P, 90)\end{array}$ & & «A la man (Flores) & \\
\hline $\begin{array}{l}\text { «Es la soberbia artífice } \\
\text { engañoso» }\end{array}$ & $\begin{array}{l}\text { «Comparación de las } \\
\text { fábricas de la soberbia } \\
\text { con las de la } \\
\text { humildad» }(P, 113)\end{array}$ & $\begin{array}{l}\text { «A la soberbia. Con el } \\
\text { ejemplo de la estatua } \\
\text { de Nabuco, muestra } \\
\text { que, estando derecha, } \\
\text { fue peligrosa y, vuelta } \\
\text { de arriba abajo, es } \\
\text { segura» }(T M, 223)^{62}\end{array}$ & & \\
\hline $\begin{array}{l}\text { «e los misterios a los } \\
\text { brindis llevas» }\end{array}$ & $\begin{array}{l}\text { «Espántase de la } \\
\text { advertencia quien tiene } \\
\text { olvidada la culpa» }(P \text {, } \\
\text { 113) }\end{array}$ & $\begin{array}{l}\text { «Al rey Baltasar, } \\
\text { cuando profanó en el } \\
\text { convite los vasos } \\
\text { sagrados del templo y } \\
\text { vio una mano, } \\
\text { comiendo, que escribía }\end{array}$ & & \\
\hline
\end{tabular}

${ }^{61}$ La relación siguiente, que es sólo una síntesis aproximativa y podría ampliarse con más ejemplos, se basa en la valiosa información que sobre los distintos testimonios ofrece la edición canónica de la poesía quevediana de José Manuel Blecua. Estructurada en musas para mayor claridad como en el análisis precedente, cita al comienzo el primer verso, tal y como figura en Parnaso; a continuación, el epígrafe incluido en 1648, en 1670 o en ambas; finalmente, el o los epígrafes con que figura en testimonios manuscritos o impresos del siglo XVII, muchos de ellos anteriores a la edición póstuma de González de Salas y Aldrete. Para mayor brevedad, uso las abreviaturas $P$ (Parnaso) y TM (Tres musas), seguidas del número de página, y sólo doy la fecha de los testimonios en la primera mención de los mismos.

${ }^{62}$ Dice Blecua «Aldrete volvió a publicar el soneto, sin duda copiándolo de una versión autógrafa» (I, p. 250). 


\begin{tabular}{|c|c|c|c|c|}
\hline & & $\begin{array}{l}\text { en la pared estas } \\
\text { palabras: Mane, Tezel, } \\
\text { Phares» (TM, 227) }\end{array}$ & & \\
\hline $\begin{array}{l}\text { «Retirado en la paz de } \\
\text { estos desiertos» }\end{array}$ & $\begin{array}{l}\text { «Algunos años antes } \\
\text { de su prisión última, } \\
\text { me envió este } \\
\text { excelente soneto desde } \\
\text { La Torre» }(P, 115)\end{array}$ & & $\begin{array}{l}\text { «Comerzio de } \\
\text { difuntos } \\
\text { contrapuntos» } \\
\text { (autógrafo, British } \\
\text { Museum) }\end{array}$ & $\begin{array}{l}\text { «Habiendo enviudado } \\
\text { y retirádose de la } \\
\text { comunicación escribió } \\
\text { este soneto» (ms. } \\
\text { 4312). }\end{array}$ \\
\hline $\begin{array}{l}\text { «Oh corvas almas, oh } \\
\text { facinorosos» }\end{array}$ & $\begin{array}{l}\text { «Sermón estoico de } \\
\text { censura morab» }(P \text {, } \\
127)\end{array}$ & & $\begin{array}{l}\text { «Sermón estoico a las } \\
\text { desórdenes de los } \\
\text { apetitos» } \\
\text { (C. antequerano) }\end{array}$ & $\begin{array}{l}\text { «Kerasbolos. Sermón } \\
\text { estoico a las } \\
\text { desórdenes de los } \\
\text { apetitos. De don } \\
\text { Francisco de Quevedo } \\
\text { y Villegas. Año 1625» } \\
\text { (ms. Harvard) }\end{array}$ \\
\hline $\begin{array}{l}\text { «No he de callar, por } \\
\text { más que con el dedo» }\end{array}$ & $\begin{array}{l}\text { «Epístola satírica y } \\
\text { censoria contra las } \\
\text { costumbres presentes } \\
\text { de los castellanos, } \\
\text { escrita a don Gaspar } \\
\text { de Guzmán, conde de } \\
\text { Olivares, en su } \\
\text { valimiento» }(P, 139)\end{array}$ & & $\begin{array}{l}\text { «Al excelentísimo } \\
\text { señor don Gaspar de } \\
\text { Guzmán, conde, } \\
\text { duque, gran canciller. } \\
\text { Don Francisco de } \\
\text { Quevedo Villegas } \\
{[\ldots] \text { deseoso de la }} \\
\text { renovación de los } \\
\text { trajes y ejercicios de la } \\
\text { nobleza española» } \\
\text { (Discuro de los tufos, de } \\
\text { Jiménez Patón, 1629) }\end{array}$ & $\begin{array}{l}\text { «Epístola de don } \\
\text { Francisco de Quevedo } \\
\text { al conde-duque de San } \\
\text { Lúcan» }(\text { C. antequerano) } \\
\text { «Carta al conde de } \\
\text { Olivares en } \\
\text { recomendación de las } \\
\text { costumbres antiguas } \\
\text { de España. De don } \\
\text { Francisco de Quevedo } \\
\text { [...] de Santiago» } \\
\text { (ms. Harvard) }\end{array}$ \\
\hline $\begin{array}{l}\text { MEIPÓMENE } \\
\text { «Yace pintado } \\
\text { amante». }\end{array}$ & $\begin{array}{l}\text { «Túmulo de la } \\
\text { mariposa» }(P, 170)\end{array}$ & & $\begin{array}{l}\text { «Túmulo a una } \\
\text { mariposa» (ms. } \\
\text { «Nápoles», sigo XVII) }\end{array}$ & \\
\hline $\begin{array}{l}\text { «Blandamente } \\
\text { descansan, } \\
\text { caminante». }\end{array}$ & $\begin{array}{l}\text { «Túmulo funeral de } \\
\text { Federico, hermano del } \\
\text { marqués Espínola» }(P \text {, } \\
\text { 155) }\end{array}$ & & $\begin{array}{l}\text { «Al túmulo de } \\
\text { Federico Espínola» } \\
\text { (ms. 3797, siglo XVII) }\end{array}$ & \\
\hline $\begin{array}{l}\text { «Mi madre tuve en } \\
\text { ásperas montañas» }\end{array}$ & $\begin{array}{l}\text { «Sepulcro de Jasón el } \\
\text { Argonauta» }(P, 157)\end{array}$ & & $\begin{array}{l}\text { «A la primera nave del } \\
\text { mundo» (Flonesy } \\
\text { «Évora») }\end{array}$ & \\
\hline $\begin{array}{l}\text { «No llegó a tanto } \\
\text { invidia de los hados» }\end{array}$ & $\begin{array}{l}\text { «Epitafio para el } \\
\text { mismo» }(P, 162)\end{array}$ & & $\begin{array}{l}\text { «A la muerte del rey de } \\
\text { Francia» (〈Évora») }\end{array}$ & $\begin{array}{l}\text { «Soneto a la muerte } \\
\text { del cuarto Enrico, rey } \\
\text { de Francia» (ms. 3797) }\end{array}$ \\
\hline $\begin{array}{l}\text { «mperio tuve un } \\
\text { tiempo, pasajero» }\end{array}$ & $\begin{array}{l}\text { «Túmulo a Colón» }(P \text {, } \\
\text { 165) }\end{array}$ & & $\begin{array}{l}\text { «A Colón, hablando a } \\
\text { una nave» («Évora») }\end{array}$ & $\begin{array}{l}\text { «Soneto al túmulo de } \\
\text { Colón» (ms. 3797) }\end{array}$ \\
\hline $\begin{array}{l}\text { «Al tronco y a la } \\
\text { fuente» }\end{array}$ & $\begin{array}{l}\text { «A una tórtola, que se } \\
\text { quejaba viuda y } \\
\text { después se halló } \\
\text { muerta» }(P, 174)\end{array}$ & & $\begin{array}{l}\text { «A una tórtola que oía } \\
\text { quejarse viuda y } \\
\text { después la halló } \\
\text { muerta» («Évora») }\end{array}$ & $\begin{array}{l}\text { «A una tórtola que se } \\
\text { halló muerta» } \\
\text { («Nápoles») }\end{array}$ \\
\hline $\begin{array}{l}\text { ERATO } \\
\text { «Salamandra frondosa } \\
\text { y bien poblada» }\end{array}$ & $\begin{array}{l}\text { «Ardor disimulado de } \\
\text { amante» }(P, 195)\end{array}$ & & $\begin{array}{l}\text { «Al Vesubio, que } \\
\text { interpoladamente es }\end{array}$ & \\
\hline
\end{tabular}




\begin{tabular}{|c|c|c|c|}
\hline & & & $\begin{array}{l}\text { jardín y volcán....” } \\
\text { (Quiñones, El monte } \\
\text { Vesubio, 1632) }\end{array}$ \\
\hline $\begin{array}{l}\text { «Esforzaron mis ojos } \\
\text { la corriente» }\end{array}$ & $\begin{array}{l}\text { «L lanto, presunción, } \\
\text { culto y tristeza } \\
\text { amorosa» }(P, 203)\end{array}$ & $\begin{array}{l}\text { «Embravecíl llorando } \\
\text { la corriente», «En lo } \\
\text { penoso de un amante } \\
\text { ausente» }(T M, 26)\end{array}$ & \\
\hline $\begin{array}{l}\text { «Cómo pudiera ser } \\
\text { hecho piadoso» }\end{array}$ & $\begin{array}{l}\text { «Celebra el cabello de } \\
\text { una dama que, } \\
\text { habiéndosele } \\
\text { mandado cortar en } \\
\text { una enfermedad, ella } \\
\text { no quiso» }(P, 223)\end{array}$ & $\begin{array}{l}\text { «Silva 28. Cabellos de } \\
\text { Aminta, que mandó } \\
\text { un médico que se los } \\
\text { cortasen en un } \\
\text { tabardillo; ella no le } \\
\text { obedeció. Es } \\
\text { agradecimiento a } \\
\text { Aminta y } \\
\text { reprehensión al } \\
\text { docton (TM, Euterpe, } \\
\text { 207) }\end{array}$ & \\
\hline $\begin{array}{l}\text { "Quien nueva sciencia } \\
\text { y arte» }\end{array}$ & $\begin{array}{l}\text { «Nueva filosofia de } \\
\text { amor, contraria a la } \\
\text { que se lee en las } \\
\text { escuelas» }(P, 227)\end{array}$ & $\begin{array}{l}\text { «Quien quisiere nueva } \\
\text { arte», «Muestra el } \\
\text { poder del amon» (TM, } \\
\text { Euterpe, 47) }\end{array}$ & \\
\hline $\begin{array}{l}\text { «Tiempo, que todo lo } \\
\text { mudas» }\end{array}$ & $\begin{array}{l}\text { «Advierte al Tiempo } \\
\text { de mayores hazañas } \\
\text { en que podrá ejercitar } \\
\text { sus fuerzas» }(P, 242)\end{array}$ & $\begin{array}{l}\text { «Al Tiempo, } \\
\text { enamorada invocando } \\
\text { su valentía contra el } \\
\text { rigor de su mab» (TM, } \\
193)^{63}\end{array}$ & \\
\hline $\begin{array}{l}\text { «i en suspiros por el } \\
\text { aire» }\end{array}$ & $\begin{array}{l}\text { «Amante ausente que } \\
\text { muere presumido de } \\
\text { su amon» }(P, 244)\end{array}$ & & $\begin{array}{l}\text { «Amante ausente y } \\
\text { desterrado, sin querer } \\
\text { su dama dar oídos a su } \\
\text { pasión» (ms. } 3940 \text {, } \\
\text { siglo XVIII) }\end{array}$ \\
\hline $\begin{array}{l}\text { «Ésta, por ser, joh Lisil, } \\
\text { la primera» }\end{array}$ & $\begin{array}{l}\text { «Ofrece a Lisi la } \\
\text { primera flor que se } \\
\text { abrió en el año» }(P \text {, } \\
267)\end{array}$ & & $\begin{array}{l}\text { «Soneto ofreciendo a } \\
\text { Belisa la primer rosa } \\
\text { que abrió el verano» } \\
\text { (ms. } 3797 \text { ) }\end{array}$ \\
\hline $\begin{array}{l}\text { «Descansa en sueño, } \\
\text { ¡oh tiemo y dulce } \\
\text { pecho» }\end{array}$ & $\begin{array}{l}\text { «A una niña muy } \\
\text { hermosa, que dormía } \\
\text { en las faldas de Lisi» }(P \text {, } \\
284)\end{array}$ & & $\begin{array}{l}\text { «Descansa del calor } \\
\text { del tiemo pecho», «El } \\
\text { mismo, a una niña que } \\
\text { dormía en las faldas de } \\
\text { una dama» } \\
\text { (C. antequerano) }\end{array}$ \\
\hline $\begin{array}{l}\text { «Ay, cómo en estos } \\
\text { árboles sombríos» }\end{array}$ & $\begin{array}{l}\text { «amenta su muerte y } \\
\text { hace epitafio a su } \\
\text { sepulcro» }(P, 29))\end{array}$ & & $\begin{array}{l}\text { «Amante que muere. } \\
\text { Silva 22» («Nápoles») }\end{array}$ \\
\hline
\end{tabular}

${ }^{63}$ Blecua (I, p. 602) advierte error por enamorado.

${ }^{64}$ Otros casos de versiones diferentes del epígrafe en el ms. 3940 de la BNE son: «Males, no os partáis de mí». «Muere de amor y entiérrase amando» $(P, 245)$; «Desesperado de mejorar su mala fortuna y deseoso de que los males le acaben» (ms. 3940). «A la sombra de un risco». «Ausente de Flori, huye sus pensamientos, y ellos le dejan» $(P, 250)$; «Un galán, desterrado y ausente de su dama, estando en el campo solo» (ms. 3940). «Tus niñas, Marica». «Pintura no vulgar de una hermosura» $(P, 252)$; «Pintura de las buenas partes de una dama, hechas por su galán, preso y ausente» (ms. 3940). 


\begin{tabular}{|c|c|c|c|}
\hline $\begin{array}{l}\text { «Pues reinando en tus } \\
\text { ojos gloria y vida» }\end{array}$ & $\begin{array}{l}\text { «Hace últimamente su } \\
\text { testamento» }(P, 297)\end{array}$ & $\begin{array}{l}\text { «ilva 24. Testamento } \\
\text { amoroso» («Nápoles») }\end{array}$ & \\
\hline $\begin{array}{l}\text { TERPSíCORE } \\
\text { «Ya está guardado en } \\
\text { la trena». }\end{array}$ & $\begin{array}{l}\text { «Carta de Escrramán a } \\
\text { la Ménde»» }(P, 341)\end{array}$ & $\begin{array}{l}\text { «Aquí se contiene la } \\
\text { adversa fortuna del } \\
\text { valiente Escarramán, } \\
\text { natural de Sevilla }[. . .] \\
\text { Cuéntase el trato de } \\
\text { otros camaradas suyos } \\
{[\ldots .] \text { y el castigo y fin }} \\
\text { de Escarramán» } \\
\text { (pliego suelto, 1613?) }\end{array}$ & \\
\hline $\begin{array}{l}\text { «Contando estaba las } \\
\text { cañas» }\end{array}$ & $\begin{array}{l}\text { «as cañas que jugó su } \\
\text { majestad cuando vino } \\
\text { el príncipe de Gales» } \\
(P, 368)\end{array}$ & $\begin{array}{l}\text { «e las fiestas en que } \\
\text { el rey nuestro señor } \\
\text { jugó cañas» («Évora») }\end{array}$ & $\begin{array}{l}\text { «A las cañas que jugó } \\
\text { su majestad, estando } \\
\text { en la corte el príncipe } \\
\text { de Gales» (ms. 3940) }\end{array}$ \\
\hline $\begin{array}{l}\text { «Todo se lo muque el } \\
\text { tiempo» }\end{array}$ & $\begin{array}{l}\text { «Los valientes y } \\
\text { tomajonas» }(P, 374)\end{array}$ & $\begin{array}{l}\text { «Baile de los valientes y } \\
\text { su germanía, y trato de } \\
\text { la vida airada» (ms. } \\
\text { 3940) }\end{array}$ & \\
\hline $\begin{array}{l}\text { «Helas, helas, por do } \\
\text { vienen» }\end{array}$ & $\begin{array}{l}\text { «as valentonas, y } \\
\text { destreza» }(P, 377)\end{array}$ & $\begin{array}{l}\text { «Baile de la destreza de } \\
\text { las armas ejecutada } \\
\text { por las damas de la } \\
\text { vida airada» (ms. 3940) }\end{array}$ & \\
\hline $\begin{array}{l}\text { «Allá va con un } \\
\text { sombrero» }\end{array}$ & $\begin{array}{l}\text { «as estafadoras» }(P \text {, } \\
390)\end{array}$ & $\begin{array}{l}\text { «a estafadora, } \\
\text { tomajona, } \\
\text { sonsacadora y } \\
\text { agarradora» (ms. 3940) }\end{array}$ & \\
\hline $\begin{array}{l}\text { TALÍA } \\
\text { «Tras vos un } \\
\text { alquimista va } \\
\text { corriendo» }\end{array}$ & $\begin{array}{l}\text { «A Dafne, huyendo de } \\
\text { Apolo» }(P, 428)\end{array}$ & $\begin{array}{l}\text { «tro del mismo. A } \\
\text { Dafne» (《Évora») }\end{array}$ & \\
\hline $\begin{array}{l}\text { «o os espantéis, } \\
\text { señora Notomía» }\end{array}$ & $\begin{array}{l}\text { «Encarece la suma } \\
\text { flaqueza de una dama» } \\
(P, 458)\end{array}$ & $\begin{array}{l}\text { «A una mujer flaca» } \\
\text { (Flons y Cancionero } \\
1628)\end{array}$ & $\begin{array}{l}\text { «Canción a una dama } \\
\text { flaca» («Évora») }\end{array}$ \\
\hline $\begin{array}{l}\text { «ye la voz de un } \\
\text { hombre que te canta» }\end{array}$ & $\begin{array}{l}\text { «Dama hermosa, entre } \\
\text { rota y remendada» } \\
(P, 461)\end{array}$ & $\begin{array}{l}\text { «A una dama } \\
\text { hermosa, rota y } \\
\text { remendada» (Flores) }\end{array}$ & $\begin{array}{l}\text { «A una dama } \\
\text { hermosa, rota y } \\
\text { presumida» (ms. 3940) }\end{array}$ \\
\hline «Óyeme riguroso» & $\begin{array}{l}\text { «Celebra la pureza de } \\
\text { una dama vinosa» } \\
(P, 462)\end{array}$ & $\begin{array}{l}\text { «A una dama hermosa } \\
\text { y borracha» (Cancioner } \\
1628)\end{array}$ & $\begin{array}{l}\text { «A una dama } \\
\text { borracha» } \\
(C . \text { antequerano) }\end{array}$ \\
\hline $\begin{array}{l}\text { «loris, la fiesta } \\
\text { pasada» }\end{array}$ & $\begin{array}{l}\text { «Fiesta de toros con } \\
\text { rejoneo al príncipe de } \\
\text { Gales, en que llovió } \\
\text { mucho» }(P, 470)\end{array}$ & $\begin{array}{l}\text { «A los toros que se } \\
\text { corrieron en Madrid } \\
\text { delante del príncipe de } \\
\text { Gales y de su } \\
\text { majestad, don Felipe } \\
\text { IV» («Évora») }\end{array}$ & \\
\hline $\begin{array}{l}\text { «Al que de la guarda } \\
\text { es» }\end{array}$ & $\begin{array}{l}\text { «Carta al conde de } \\
\text { Sástago desde Madrid, } \\
\text { habiendo ido con su } \\
\text { majestad a Barcelona» } \\
(P, 488)\end{array}$ & $\begin{array}{l}\text { «on Francisco de } \\
\text { Quevedo al conde de } \\
\text { Sástago, estando en } \\
\text { Valencia» (ms. 3797) }\end{array}$ & \\
\hline
\end{tabular}




\begin{tabular}{|c|c|c|c|}
\hline $\begin{array}{l}\text { «Tomando estaba } \\
\text { sudores» }\end{array}$ & $\begin{array}{l}\text { «Cura una moza en } \\
\text { Antón Martín la tela } \\
\text { que mantuvo» }(P, 505)\end{array}$ & $\begin{array}{l}\text { «A una moza que } \\
\text { entró a tomar sudores } \\
\text { en el hospital de } \\
\text { Antón Martín, en } \\
\text { Madrid» («Évora») }\end{array}$ & $\begin{array}{l}\text { «A una moza que } \\
\text { entró a tomar sudores } \\
\text { en el hospital de } \\
\text { Antón Martín» (ms. } \\
\text { 3940) }\end{array}$ \\
\hline $\begin{array}{l}\text { «uitándose está } \\
\text { Medoro» }\end{array}$ & $\begin{array}{l}\text { «Burla el poeta de } \\
\text { Medoro, y Medoro de } \\
\text { los pares» }(P, 522)\end{array}$ & $\begin{array}{l}\text { «Medoro, haciendo } \\
\text { burla de los doce } \\
\text { Pares, por ser dueño } \\
\text { de Angélica» (ms. } \\
\text { 3940) }\end{array}$ & \\
\hline $\begin{array}{l}\text { «Ciego eres, Amor, y } \\
\text { no» }\end{array}$ & $\begin{array}{l}\text { «eclama contra el } \\
\text { Amon» }(P, 530)\end{array}$ & & $\begin{array}{l}\text { «Al Amor, diciéndole } \\
\text { por proverbio su } \\
\text { origen y calidades de } \\
\text { sus proegenitores» } \\
\text { (ms. 3940) }\end{array}$ \\
\hline $\begin{array}{l}\text { «anzanares, } \\
\text { Manzanares» }\end{array}$ & $\begin{array}{l}\text { «escubre } \\
\text { Manzanares secretos } \\
\text { de los que en él se } \\
\text { bañan» }(P, 544)\end{array}$ & $\begin{array}{l}\text { «ntroduce a } \\
\text { Manzanares para } \\
\text { descubrir los secretos } \\
\text { de los que en él se } \\
\text { bañan» (ms. BMP 102, } \\
\text { siglo XVII) }\end{array}$ & $\begin{array}{l}\text { «Pregunta a } \\
\text { Manzanares el género } \\
\text { de sirenas que le asiste, } \\
\text { y él lo dice» (ms. 3940) }\end{array}$ \\
\hline $\begin{array}{l}\text { «Mensajero soy, } \\
\text { señora» }\end{array}$ & $\begin{array}{l}\text { «Lición de una tía a } \\
\text { una muchacha, y ella } \\
\text { muestra cómo la } \\
\text { aprende» }(P, 547)\end{array}$ & $\begin{array}{l}\text { «Estafadora y } \\
\text { tomajona y sus } \\
\text { documentos y liciones } \\
\text { para sonsacan (ms. } \\
3940)\end{array}$ & \\
\hline $\begin{array}{l}\text { «Estamos entre } \\
\text { cristianos?》 }\end{array}$ & $\begin{array}{l}\text { «Con nombre } \\
\text { supuesto, se queja de } \\
\text { una madre y de una } \\
\text { hija» }(P, 551)\end{array}$ & $\begin{array}{l}\text { «A una madre, que } \\
\text { pedía la paga del virgo } \\
\text { de su hija a quien no se } \\
\text { le había quitado» (ms. } \\
\text { 3940) }\end{array}$ & \\
\hline $\begin{array}{l}\text { "A buen puerto habéis } \\
\text { llegado» }\end{array}$ & $\begin{array}{l}\text { «Responde a la } \\
\text { sacaliña de unas } \\
\text { pelonas» }(P, 555)\end{array}$ & $\begin{array}{l}\text { «Responde a la } \\
\text { sacaliña de unas } \\
\text { pelonas» (Maravillas del } \\
\text { Pamaso, 1637) }\end{array}$ & $\begin{array}{l}\text { «A unas damas, que la } \\
\text { una era roma, y le } \\
\text { pedían dineros y de } \\
\text { merendan (ms. 3940) }\end{array}$ \\
\hline $\begin{array}{l}\text { «Cubriendo con } \\
\text { cuatro cuemos» }\end{array}$ & $\begin{array}{l}\text { «En la simulada figura } \\
\text { de unas prendas } \\
\text { ridículas, burla de la } \\
\text { vana estimación que } \\
\text { hacen los amantes de } \\
\text { semejantes amores» } \\
(P, 557)\end{array}$ & $\begin{array}{l}\text { «A un sacristán, } \\
\text { amante ridículo» } \\
\text { (Maravillas) }\end{array}$ & $\begin{array}{l}\text { «A un sacristán, } \\
\text { haciendo alarde de los } \\
\text { favores de su dama y } \\
\text { dejándolos en el } \\
\text { campo» (ms. 3940) }\end{array}$ \\
\hline «A la jineta sentada» & $\begin{array}{l}\text { «uejas de una } \\
\text { cortesana viéndose } \\
\text { ociosa» }(P, 556)\end{array}$ & $\begin{array}{l}\text { «Dama cortesana } \\
\text { lamentándose de su } \\
\text { pobreza y diciendo la } \\
\text { causa» (m. 3940) }\end{array}$ & \\
\hline $\begin{array}{l}\text { «Al Prado vais, la mi } \\
\text { yegua» }\end{array}$ & $\begin{array}{l}\text { «Envía una yegua a } \\
\text { descansar al Prado» } \\
(P, 560)\end{array}$ & $\begin{array}{l}\text { "A una yegua muy } \\
\text { flaca, vieja y matada, } \\
\text { que echó al Prado» } \\
\text { (ms. 3940) }\end{array}$ & $\begin{array}{l}\text { «uevedo. A una } \\
\text { yegua suya muy vieja y } \\
\text { flaca» (ms. } 4117 \text {, siglo } \\
\text { XVII) }\end{array}$ \\
\hline «De un molimiento de & «Testamento de don & «Testamento y última & \\
\hline
\end{tabular}




\begin{tabular}{|c|c|c|c|c|}
\hline güesos» & Quijote» $(P, 563)$ & & $\begin{array}{l}\text { voluntad de don } \\
\text { Quijote de la Mancha» } \\
\text { (ms. 3940) }\end{array}$ & \\
\hline $\begin{array}{l}\text { «Un moño que, } \\
\text { aunque traslado» }\end{array}$ & $\begin{array}{l}\text { «Femenina cabellera, } \\
\text { que predica a las } \\
\text { verdaderas pelambres» } \\
(P, 578)\end{array}$ & & $\begin{array}{l}\text { «Moño postizo } \\
\text { hablando con los } \\
\text { copetes originales y } \\
\text { verdaderos» ( } \mathrm{ms} \text {. } \\
3940)\end{array}$ & $\begin{array}{l}\text { «Śtira a las mujeres } \\
\text { que traen moños } \\
\text { postizos« («Évora») }\end{array}$ \\
\hline $\begin{array}{l}\text { «ebe de haber ocho } \\
\text { días» }\end{array}$ & $\begin{array}{l}\text { «Consultación de los } \\
\text { gatos, en cuya figura } \\
\text { también se castigan } \\
\text { costumbres y aruños» } \\
(P, 591 ; \text { Sueñosy } \\
\text { discursos, } 1627 \text {; } \\
\text { Enseñanza entretenida, } \\
1648)\end{array}$ & & $\begin{array}{l}\text { «Cortes, junta y } \\
\text { cabildo de los gastos, y } \\
\text { queja de los mal } \\
\text { acomodados» (ms. } \\
3940 \text { ) }\end{array}$ & \\
\hline «Érase que se era» & $\begin{array}{l}\text { «Suceso que, aunque } \\
\text { parece de conseja, fue } \\
\text { verdadero» }(P, 648)\end{array}$ & & «uguete» (Maravillas) & $\begin{array}{l}\text { «Pintura de una vieja y } \\
\text { su vida y costumbres, } \\
\text { y castigo que la dieron» } \\
\text { (ms. } 3940)\end{array}$ \\
\hline $\begin{array}{l}\text { EUTERPE } \\
\text { «Embravecíllorando } \\
\text { la corriente» }\end{array}$ & $\begin{array}{l}\text { «Esforzaron mis ojos } \\
\text { la corriente», «Llanto, } \\
\text { presunción, culto y } \\
\text { tristeza amorosa» } \\
(P, 203)\end{array}$ & $\begin{array}{l}\text { «En lo penoso de un } \\
\text { amante ausente» } \\
(T M, 26)\end{array}$ & & \\
\hline $\begin{array}{l}\text { «Salió trocada en } \\
\text { menudos» }\end{array}$ & & $\begin{array}{l}\text { «Romance burlesco» } \\
(T M, 75)\end{array}$ & $\begin{array}{l}\text { «Romance» } \\
\text { (Cancioner 1628) } \\
\text { «Romance a dos } \\
\text { mujeres flacas y altas» } \\
\text { («Évora») }\end{array}$ & $\begin{array}{l}\text { «Pinta el haber } \\
\text { encontrado dos } \\
\text { mujeres fieras una } \\
\text { noche» (mss. } 4067 \mathrm{y} \\
3708)^{65}\end{array}$ \\
\hline $\begin{array}{l}\text { CALÍOPE } \\
\text { «Diste crédito a un } \\
\text { pino» }\end{array}$ & & $\begin{array}{l}\text { «Silva tercera. La mina } \\
\text { de oro contra la } \\
\text { codicia» }(T M, 137)\end{array}$ & $\begin{array}{l}\text { «A una mina» (Flores) } \\
\text { «A los que pasan el } \\
\text { mar. Madrigal» } \\
\text { (C. antequerano) }\end{array}$ & $\begin{array}{l}\text { «Silva 9. A uno que } \\
\text { después de haber } \\
\text { pasado tempestades, } \\
\text { cavaba una mina de } \\
\text { oro» («Évora») }\end{array}$ \\
\hline $\begin{array}{l}\text { «ónde vas, ignorante } \\
\text { navecilla» }\end{array}$ & & $\begin{array}{l}\text { «Silva quinta. } \\
\text { Exhortación a una } \\
\text { nave nueva al entrar } \\
\text { en el agua» }(T M, 145)\end{array}$ & $\begin{array}{l}\text { «Silva. Exhortando a } \\
\text { una nave nueva al } \\
\text { entrar en el agua» } \\
\text { («Évora») }\end{array}$ & $\begin{array}{l}\text { «A una nave» (segunda } \\
\text { parte Flones, 1611) }\end{array}$ \\
\hline $\begin{array}{l}\text { «Qué tienes que } \\
\text { contar, reloj molesto» }\end{array}$ & & $\begin{array}{l}\text { «l reloj de arena» } \\
(T M, 152)\end{array}$ & $\begin{array}{l}\text { «Reloj de arena» } \\
\text { (Flores, 1611) }\end{array}$ & $\begin{array}{l}\text { «Madrigal de don } \\
\text { Francisco de Quevedo }\end{array}$ \\
\hline
\end{tabular}

${ }^{65}$ Añádanse a los señalados otros casos recogidos también en el ms. 3940: «Una incrédula de años». «Acuerda al papel su origen humilde» $(P, 499)$; «A una vieja que andaba buscando trapos para papel» (3940). «Viejo verde, viejo verde». «Desmiente a un viejo por la barba» $(P, 500)$; «A un viejo que se teñía la barba y cabello» (3940). «Una niña de lo caro». "Toros y cañas en que entró el rey nuestro señor don Felipe IV» $(P, 501)$; «A un juego de cañas [en] que entró el rey don Felipe cuarto» (3940). «Fulanito, Citanito». «Censura contra los profanos disciplinantes» $(P, 534)$; «A un diciplinante que salió muy galán el jueves santo en la Corte» (3940). «iQué preciosos son los dientes» $(P, 540)$; «A algunos miembros y partes del cuerpo que son celebrados de los poetas» (3940). «Cruel llaman a Nerón». «Jocosa defensa de Nerón y del señor rey don Pedro de Castilla» $(P, 542)$; «Paradoja de Nerón emperador y don Pedro, rey de Castilla» (3940). 


\begin{tabular}{|c|c|c|c|}
\hline & & & $\begin{array}{l}\text { al reloj de arenas } \\
\text { (C. antequerano) }\end{array}$ \\
\hline $\begin{array}{l}\text { «En cárcel de metal, } \\
\text { joh atrevimiento» }\end{array}$ & $\begin{array}{l}\text { «Silva II. Execración } \\
\text { contra el inventor de la } \\
\text { artillería» }(T M, 157)\end{array}$ & $\begin{array}{l}\text { «Silva 18. Al inventor } \\
\text { de la artillería» } \\
\text { («Nápoles») }\end{array}$ & $\begin{array}{l}\text { «Silva XI. Al inventor } \\
\text { de la artillería» } \\
\text { («Évora») }\end{array}$ \\
\hline $\begin{array}{l}\text { «Estas que veis aquí } \\
\text { pobres y escuras» }\end{array}$ & $\begin{array}{l}\text { «A los huesos de un } \\
\text { rey que se hallaron en } \\
\text { un seplucro, } \\
\text { ignorándose, y se } \\
\text { conoció por los } \\
\text { pedazos de una } \\
\text { corona» }(T M, 160)\end{array}$ & $\begin{array}{l}\text { «VIII silva. A los } \\
\text { huesos de un rey» } \\
\text { («Évora») } \\
\text { «A los güesos de un } \\
\text { rey en su sepulcro } \\
\text { destrozado» } \\
\text { (C. antequerano) }\end{array}$ & $\begin{array}{l}\text { «Silva 19. A los huesos } \\
\text { de un rey que en un } \\
\text { túmulo, ya gastado el } \\
\text { epitafio, estaban, y sólo } \\
\text { por una corona que } \\
\text { estaba dentro se } \\
\text { conoció su dignidad» } \\
\text { («Nápoles») }\end{array}$ \\
\hline «De tu peso vencido» & $\begin{array}{l}\text { «ilva 14. A un ramo, } \\
\text { que se desgajó con el } \\
\text { peso de su fruta» } \\
(T M, 168)\end{array}$ & $\begin{array}{l}\text { «Silva 3. A un ramo, } \\
\text { desgajado de su fruta, } \\
\text { a cuya sombra solía } \\
\text { Fabio aguardar a } \\
\text { Aminta» (〈Évora») }\end{array}$ & $\begin{array}{l}\text { «A un ramo, desgajado } \\
\text { con el peso de su } \\
\text { fruta» («Nápoles») }\end{array}$ \\
\hline $\begin{array}{l}\text { «Tú, si en cuerpo } \\
\text { pequeño» }\end{array}$ & $\begin{array}{l}\text { «Silva 25. El pincel» } \\
(T M, 190) \\
\text { «Y el famoso español, } \\
\text { que no hablaba», «En } \\
\text { alabanza de la pintura } \\
\text { de algunos pintores } \\
\text { españoles» (TM, 201) }\end{array}$ & $\begin{array}{l}\text { «Silva 7. Al pinceb» } \\
\text { (Évora) }\end{array}$ & $\begin{array}{l}\text { «Silva 19. El pincel» } \\
\text { («Nápoles») }\end{array}$ \\
\hline $\begin{array}{l}\text { «El instrumento } \\
\text { artífice de muros» }\end{array}$ & $\begin{array}{l}\text { «A don Jerónimo de } \\
\text { Mata en el libro de las } \\
\text { tristezas de Amarilis» } \\
(T M, 205)\end{array}$ & & $\begin{array}{l}\text { «A don Jerónimo de } \\
\text { Mata en el libro de las } \\
\text { tristezas de Amarilis, } \\
\text { insigne músico de } \\
\text { laúd. Silva 15» } \\
\text { («Nápoles») }\end{array}$ \\
\hline $\begin{array}{l}\text { «Con qué culpa tan } \\
\text { grave» }\end{array}$ & «El sueño» $(T M, 134)$ & $\begin{array}{l}\text { «Al sueño» (Flores } \\
1611, \text { Nápoles, } \\
\text { «Évora», C. antequerano) }\end{array}$ & \\
\hline $\begin{array}{l}\text { «Qué de robos han } \\
\text { visto el inviemo» }\end{array}$ & $\begin{array}{l}\text { «Farmaceutria o } \\
\text { medicamentos } \\
\text { enamorados (TM, } \\
147)\end{array}$ & $\begin{array}{l}\text { «Farmaceutria» } \\
\text { («Nápoles», Flones } \\
\text { 1611) }\end{array}$ & $\begin{array}{l}\text { «XII Silva. A unos } \\
\text { hechizos amorosos» } \\
\text { («Évora») }\end{array}$ \\
\hline «Aquí la vez postrera» & $\begin{array}{l}\text { «Amante que vuelve a } \\
\text { ver la fuente de donde } \\
\text { se ausentó» }(T M, 169)\end{array}$ & $\begin{array}{l}\text { «A una fuente» } \\
\text { («Nápoles») }\end{array}$ & $\begin{array}{l}\text { «Silva 4. A una fuente } \\
\text { donde se despidió de } \\
\text { Aminta, y, forzado de } \\
\text { voluntad, volvió luego, } \\
\text { y no la hallándola alli, } \\
\text { pregunta por ella a la } \\
\text { fuente» (《Évora») }\end{array}$ \\
\hline «A vosotras, estrellas». & $\begin{array}{l}\text { «Himno a las estrellas» } \\
(T M, 172)\end{array}$ & $\begin{array}{l}\text { «Himno a las estrellas» } \\
\text { («Nápoles») }\end{array}$ & \\
\hline «O sea que, olvidado» & $\begin{array}{l}\text { «El yelmo de Segura } \\
\text { de la Sierra, monte } \\
\text { muy alto al Austro» } \\
(T M, 174)\end{array}$ & $\begin{array}{l}\text { «Al cerro altísimo que } \\
\text { de la forma en que } \\
\text { remata llaman Yelmo } \\
\text { de la Sierra de Sigura, } \\
\text { donde nasce }\end{array}$ & $\begin{array}{l}\text { «Al Hielmo de Sigura } \\
\text { de la Sierra, que tiene } \\
\text { esa forma, donde nace } \\
\text { Guadalquivir y otros } \\
\text { ríos» («Évora») }\end{array}$ \\
\hline
\end{tabular}




\begin{tabular}{|c|c|c|c|}
\hline & & & $\begin{array}{l}\text { Guadalquivir y otros } \\
\text { ríos» («Nápoles») }\end{array}$ \\
\hline $\begin{array}{l}\text { URANIA } \\
\text { «ea que descansando } \\
\text { la corriente» }\end{array}$ & $\begin{array}{l}\text { «A la custodia de } \\
\text { cristal que dio el duque } \\
\text { de Lerma a San Pablo } \\
\text { de Valladolid, para el } \\
\text { Santísimo } \\
\text { Sacramento» }(P, 18)\end{array}$ & $\begin{array}{l}\text { «A un hermosísimo } \\
\text { pedazo de cristal, de } \\
\text { que el duque de } \\
\text { Lerma con grande } \\
\text { gusto hizo una } \\
\text { custodia, que, para el } \\
\text { Santísimo Sacramento, } \\
\text { dio al convento de san } \\
\text { Pablo de Valladolid. } \\
\text { Dice poéticamente las } \\
\text { opiniones que hay } \\
\text { acerca de la naturaleza } \\
\text { del cristal» (TM, p. } \\
223 \text { ) }\end{array}$ & \\
\hline $\begin{array}{l}\text { «Adónde, Pedro, } \\
\text { están las valentías» }\end{array}$ & & $\begin{array}{l}\text { «A san Pedro, cuando } \\
\text { negó a Cristo señor } \\
\text { nuestro» }(T M, \text { p. } 242)\end{array}$ & $\begin{array}{l}\text { «A san Pedro, cuando } \\
\text { cantó el gallo» } \\
\text { («Évora») }\end{array}$ \\
\hline $\begin{array}{l}\text { «Viendo el mísero } \\
\text { Judas que, vendido» }\end{array}$ & & $\begin{array}{l}\text { «A Judas Escariote, } \\
\text { cuando vendió a } \\
\text { Cristo señor nuestro» } \\
(T M, 243)\end{array}$ & $\begin{array}{l}\text { «A Judas, sobre } \\
\text { vender el ungüento de } \\
\text { la Magdalena» } \\
\text { («Évora») }\end{array}$ \\
\hline $\begin{array}{l}\text { «Enséñame, cristiana } \\
\text { musa mía» }\end{array}$ & & $\begin{array}{l}\text { «Poema heroico a } \\
\text { Cristo resucitado» } \\
(T M, 264)\end{array}$ & $\begin{array}{l}\text { «oema de la } \\
\text { resurrección»» } \\
(« \text { Évora») })^{66}\end{array}$ \\
\hline $\begin{array}{l}\text { POEMAS TEMPRANOS } \\
\text { (previos a Pamaso y no } \\
\text { recogidos en éste) } \\
\text { «Yace en esta tierra } \\
\text { fría» }\end{array}$ & & & $\begin{array}{l}\text { «A Celestina» (Flones y } \\
\text { Cancioner 1628) }\end{array}$ \\
\hline $\begin{array}{l}\text { «En aqueste } \\
\text { enterramiento» }\end{array}$ & & & $\begin{array}{l}\text { "A un avariento» } \\
\text { (Flones y Cancionem } \\
1628 \text { ) }\end{array}$ \\
\hline $\begin{array}{l}\text { «Aquí yace Mosén } \\
\text { Diego» }\end{array}$ & & & $\begin{array}{l}\text { «A un cristiano nuevo, } \\
\text { junto al altar de San } \\
\text { Antonio» (Flones y } \\
\text { Cancioner 1628) }\end{array}$ \\
\hline $\begin{array}{l}\text { «No sé a cuál crea de } \\
\text { las dos» }\end{array}$ & & & $\begin{array}{l}\text { "A una vieja que traía } \\
\text { una muerte de oro» }\end{array}$ \\
\hline
\end{tabular}

${ }^{66}$ Además de los mencionados en esta musa, ténganse en cuenta los siguientes, no considerados para las conclusiones, porque el manuscrito mencionado podría ser posterior a la edición de Tres musas. «Con sacrílega mano el insolente». «Dice que se quebraron las piedras de invidia de la cruz, y acuerda cuando le quisieron apedrear los judíos y se desapareció» $(T M$, p. 219); «Da la razón por que se quiebran las piedras en la muerte de Nuestro Señor, acordándose cuando los judíos quisieron apedrear a su divina majestad y se desapareció» (ms. 2244). «Cuando escribiste en el sagrado cerro». «Las piedras a Dios, con el lugar cuando Moisén quebró las piedras en que estaba escrita la ley» (TM, p. 220); «Prosigue Quevedo. Las piedras hablan con el lugar cuando Moisñen rompió las piedras en que estaba escrita la ley» (ms. 2244). «El ver correr de Dios la sangre clara». "Por qué, habiendo muchas madres muerto de lástima de ver muertos sus hijos, amando Nuestra Señora más a su hijo que todas, no murió de lástima» (TM, p. 220); «Por qué, habiendo muchas madres muerto de oír o ver las muertes de sus hijos, siendo sin comparación mayor el amor de la Virgen María, Nuestra Señora, para con nuestro señor Jesucristo, su preciosísimo hijo, no murió de dolor» (ms. 2244). 


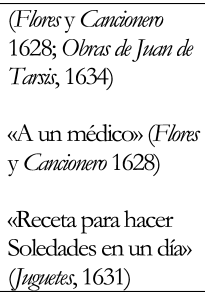

\section{BIBLIOGRAFÍA CITADA}

Anacreónticas (1981). M. Brioso Sánchez (ed.). Madrid: CSIC.

Antología de poesía erótica griega (2009). José Luis Calvo Martínez (ed.). Madrid: Cátedra.

Antología palatina (epigramas helenísticos) (1978). M. Fernández-Galiano (ed.). Madrid: Gredos.

Antología palatina II. La guirnalda de Filipo (2004). G. Galán Vioque (ed.). Madrid: Gredos.

Bembo, P. Rime (1569). Venecia: Gabriel Giolito de Ferrari. Ejemplar de la Biblioteca de Menéndez Pelayo, con signatura (715).

Boiardo, M. M (1998). Amorum libri tres. Torino: Giulio Einaudi Editore.

Calderón, J. A (1896). Segunda parte de las Flores de poetas ilustres de España ordenada por Juan Antonio Calderón, Juan Quirós de los Ríos y Francisco Rodríguez Marín (anotación de). Sevilla: Imprenta de E. Rasco.

Cancionero antequerano. I. Variedad de sonetos (1988). J. Lara Garrido (ed.). Málaga: Diputación Provincial.

Carilla, E. (1986). «Quevedo y su soneto Desde la Torre (Un elogio hispánico de libros)», Philologica Hispaniensia in honorem Manuel Alvar. Vol. III, pp. 47-60. Madrid: Gredos.

Catulo (1989). Poésies, George Lafaye (ed.). Paris: Les Belles Lettres.

Crosby, J. O. (1966). «A New Edition of Quevedo's Poetry», Hispanic Review, 34, pp. 328337.

Crosby, J. O. (1973). «Has Quevedo's Poetry been edited?», Hispanic Review, 41, pp. 627638.

Crosby, J. O. (1966). «La huella de González de Salas en la poesía de Quevedo editada por Pedro Aldrete», Homenaje a A. Rodríguez Moñino. I, pp. 111-123. Madrid.

Crosby, J. O. (1967). En torno a la poesía de Quevedo. Madrid: Castalia.

Dante. (2002). Rime, Domenico de Robertis (ed.). Fireze: Casa Editrice Le Lettere.

Egido, A. (1982). «Variaciones sobre la vid y el olmo en la poesía de Quevedo: 'Amor constante más allá de la muerte'», Academia Literaria Renacentista. II. Salamanca: Universidad, pp. 213-232.

Espinosa, P., ed., (2006). Primera parte de Flores de poetas ilustres de España, Ignoria Pepe Sarno y José-María Reyes Cano (eds.). Madrid: Cátedra.

Estacio (1607). Opera. Antuerpiae: Martini Nutii, 1607. Ejemplar de la Biblioteca Nacional de España, con signatura 2/17575.

Estacio. P. Papini Stati Silvae, A. Marastoni Lipsiae (ed.). Versión virtual de Bibliotheca Augustana.

Ettinghausen, H. (1972). «Un nuevo manuscrito autógrafo de Quevedo», Boletín de la Real Academia Española. Vol. LII, pp. 211-279.

Fernández Mosquera, S. (1999). La poesía amorosa de Quevedo. Disposición y estilo desde Canta sola a Lisi. Madrid: Gredos. 
Góngora, L. de (2005). Edición facsímil del «manuscrito Chacón» Alicante: de la Biblioteca Virtual Miguel de Cervantes, Obras de D. Luis de Góngora, tomos I, II y III, custodiado en la Biblioteca Nacional de España, con signatura res. 45.

González de Salas, J. A. (1633). Ilustración al libro de Poética de Aristóteles. Madrid: Franc Martínez. Ejemplar de la Biblioteca de Menéndez Pelayo, con signatura (12839), con anotaciones autógrafas de Quevedo.

González de Salas, J. A. (1770). Nueva idea de la tragedia antigua, o Ilustración última al libro singular de Poética de Aristóteles Estagirita, Antonio Sancha (ed.). Madrid.

González de Salas, J. A. (2003). Nueva idea de la tragedia antigua, Luis Sánchez Laílla (ed. y estudio). 2 vols. Kassel: Reichenberger.

Groto, L. (1610). Rime. Venecia: Ambrossio Dei. Ejemplar de la Biblioteca Nacional de España, con signatura 3/48399.

Herrera, F. de (1619), (Versos. Sevilla: Gabriel Ramos Vejarano. Ejemplar de la Biblioteca del Seminario Diocesano de Vitoria-Gasteiz (con anotaciones autógrafas de Quevedo), con signatura ms. 179 .

Horacio. Opera (1605). París: Bartholomaeum Macaeum. Ejemplar de la Biblioteca de Menéndez Pelayo, con signatura (23585).

Horacio. Opera (1560). Poemata omnia. Salmanticae: Ioannem Mariam à Terranoua. Ejemplar de la Biblioteca Nacional de España, con signatura R/40577.

Juvenal. Satyrae (1532). Ludguni: Melchioris et Gasparis Trechsel, 1532. Ejemplar de la Biblioteca Nacional de España, con signatura 3/45122.

León, L. de (1631). Obras propias y traducciones, Francisco de Quevedo (ed.). Milán: Phelippe Guisolti, 1631. Ejemplar de la Biblioteca de Menéndez Pelayo, con signatura (661).

Leonardo de Argensola, L. y B. Rimas (1634). Zaragoza: Hospital Real. Ejemplar de la Biblioteca de Menéndez Pelayo, con signatura (1284).

Marcial (1607). Epigrammatum libri XV. París: Michaelem Sonnium,. Ejemplar de la Biblioteca de Menéndez Pelayo, con signatura (11780).

Marino, G. B. (1616). La Lira. Venecia: G. B. Ciotti. Ejemplar de la Biblioteca de Menéndez Pelayo, con signatura (1384).

Marino, G. B. (1609). Rime. Venecia: Bernardo Giunti y G. B. Ciotti, 1609. Ejemplar de la Biblioteca de Menéndez Pelayo, con signatura (1379).

Moore, R. (1989). «Diferent kinds of failure: some comments on Quevedo's revisions to 'Miré los muros de la patria mía'», Modern Language Review, 84, 1, pp. 66-76.

Opere scelte di Giovanni Battista Marino e dei marinisti (1976). Giovanni Getto (ed.). Torino: Unione Tipografico-Editrice Torinese. Vol. I.

Ovidio (1930). Les Amours. Henri Bornecque (ed.). Paris: Les Belles Lettres.

Persio (1532). Satyrae. Ludguni: Melchioris et Gasparis Trechsel. Ejemplar de la Biblioteca Nacional de España, con signatura 3/45122.

Petrarca, F. (2006). Cancionero, Jacobo Cortines (ed.). Madrid: Cátedra. 2 vols.

Poesías germanescas (1945). John M. Hill Bloomington (ed.). Indiana University.

Poetas líricos griegos (1911). Madrid: Librería de Perlado, Páez y Cía., Sucesores de Hernando. Propercio. Élégies (2005). Simone de Viarre (ed.). Paris: Les Belles Lettres.

Quevedo, F. de (2011). Poesía amorosa (Erato, sección primera). A. Rey y M. J. Alonso Veloso (eds.). Pamplona: Eunsa.

Quevedo, F. de (1998). Un Heráclito cristiano, Canta sola a Lisi y otros poemas. L. Schwartz e I. Arellano (eds.). Barcelona: Crítica.

Quevedo, F. de (1609). Anacreon castellano, con paráfrasis y comentarios. Manuscrito de la Biblioteca Nacional de España, con signatura MSS/17529.

Quevedo, F. de (1648). El Parnaso español, monte en dos cumbres dividido, con las nueve musas castellanas. Madrid: Díaz de la Carrera. 
Quevedo, F. de. Heráclito cristiano. Copias del manuscrito Asensio (hoy en paradero desconocido) y del Cancionero de 1628. En la Biblioteca Universitaria de Zaragoza, con signatura M-247.

Quevedo, F. de (2001). La musa Clío del Parnaso español de Quevedo. I. Arellano y V. Roncero (eds.). Navarra: Eunsa.

Quevedo, F. de (1670). Las tres musas últimas castellanas. Segunda cumbre del Parnaso español. Madrid: Imprenta Real.

Quevedo, F. de (1648). Manuscrito XIV.E.46, autógrafo, de la Biblioteca Nazionale de Nápoles, ff. 115-165v.

Quevedo, F. de (1969). Obra poética, J.M. Blecua (ed.). Madrid: Castalia, 1969. 4 vols.

Rey, A., ed., (1999). Quevedo. Poesía moral (Polimnia). Támesis: Madrid.

Rey, A. (2006). «La colección de silvas de Quevedo: propuesta de inventario», MLN, 2006, 121, pp. 7-277.

Schwartz, L. e I. Arellano, eds. (1989). Quevedo, Poesía selecta. Barcelona: PPU.

Tasso, T. (1592). Delle Rime. Brescia. Ejemplar de la Biblioteca Nacional de España, con signatura $3 / 26542$.

Tasso, T. (1934). Poesie. Milano-Roma: Rizzoli \& C. Editori, 1934.

Tibulo (1990). Elegías, Edición de Hugo Francisco Bauzá. Madrid: CSIC.

Vega y Carpio, L. de (1983). Rimas humanas y divinas del licenciado Tomé de Burguillos, en J.M. Blecua. (ed.), Obras poéticas. Barcelona: Planeta.

Fecha de recepción: 26 de octubre de 2009

Fecha de aceptación: 18 de junio de 2010 